\title{
Kâşif Dehrî: Emrâz-ı Müzmine ve Sâriyeden Verem: İbtidâsı, Edvârı, Sûret-i Tevakkî ve Tedâvîsi
}

\author{
Kâşif Dehrî: Emrâz-ı Müzmine ve Sâriyeden Verem: İbtidâsı, Edvârı, Sûret-i Tevakkî ve Tedâvîsi
}

\author{
Aylin Koç Giannopoulos* - Zuhal Kültüral ${ }^{* *}$
}

\begin{abstract}
The term "Illness" describes the modifications in an organism that results in it's health deterioration. In the course of history, in societies engaging with hunting and collecting, people had generally lost their lives due to environmental reasons and hunting accidents. In agricultural societies, infectious diseases transmitted by air, water, food as well as vector-borne diseases (parasitic insects such as lice, flies, ticks, fleas) resulting in epidemics or pandemics have caused death of many people. Such outbreaks could only be taken under control with disease-specific discovered vaccines. Tuberculosis also known as Phthisis is among these diseases that caused the deaths of thousands of people in the previous centuries both in the world and Anatolia and was finally taken under control with vaccine. The word verem (tuberculosis) is a medical term of Arabic origin and is defined in the dictionaries as "infectious, febrile illness caused by Koch bacillus, tuberculosis" which is located in any organ throughout the body, especially the lungs. The Romans named this disease phytisis, meaning wheezing and spitting out sputum with coughing. In Turkish, the most common expression for tuberculosis is ince hastalık (delicate disease). In this study; Hüseyin Kâmî’s book Emrâz-ı Müzmine and Sâriyeden Verem: Ibtidâsl, Edvârl, Sûret-i Tevakkî and Tedâvîsi was examined. He wrote it using the pseudonym Kâşif Dehrî. The book was published by Sancakcıyan in Istanbul in Hijri 1331 / Gregorian 1915 and has 42 pages. The work consists of the following sub-titles: What is Tuberculosis? Causes of tuberculosis spread; The onset of tuberculosis; Various symptoms at the beginning of the tuberculosis; Susceptibility to tuberculosis; Treatment methods of tuberculosis; Nutrition of tuberculosis patients.
\end{abstract}

Structured Abstract: The term "Illness" describes the modifications in an organism that results in it's health deterioration. In the course of history, in societies engaging with hunting and collecting, people had generally lost their lives due to environmental reasons and hunting accidents. In agricultural societies, infectious diseases transmitted by air, water, food as well as vector-borne diseases (parasitic insects such as lice, flies, ticks, fleas) resulting in epidemics or pandemics have caused death of many people. Such outbreaks could only be taken under control with disease-specific discovered vaccines. Outbreaks, the history of which is as old as human history and worsens human life, have been the subject of many studies. In both medical history and general history researches; subjects such as where and how infectious diseases have spread, what measures have been taken to prevent outbreaks and its political, sociological, psychological and economic consequences are discussed in details.

\footnotetext{
${ }^{*}$ Doç. Dr., Marmara Üniversitesi, Fen-Edebiyat Fakültesi, Türk Dili ve Edebiyatı Bölümü Assoc. Prof. Dr., Marmara University, Faculty of Arts and Sciences, Turkish Language and Literature ORCID 0000-0002-0699-6932

kocayl@gmail.com

** Prof. Dr., Marmara Üniversitesi, Fen-Edebiyat Fakültesi, Türk Dili ve Edebiyatı Bölümü

Prof. Dr., Marmara University, Faculty of Arts and Sciences, Turkish Language and Literature

ORCID 0000-0001-8098-5687

zuhal.kultural@marmara.edu.tr

Cite as/ Atıf: Giannopoulos Koç, A., Kültüral, Z. (2020). Kâşif Dehrî: Emrâz-1 Müzmine ve Sâriyeden Verem: İbtidâs1,

Edvârı, Sûret-i Tevakkî ve Tedâvîsi. Turkish Studies, 15(4), 423-450. https://dx.doi.org/10.7827/TurkishStudies.44337

Received/Geliş: 18 June/Haziran 2020

Accepted/Kabul: 10 August/Ağustos 2020

Copyright $(\mathrm{C}$ MDE, Turkey

Checked by plagiarism software

Published/Yayın: 30 August/Ağustos 2020

CC BY-NC 4.0
} 
The Ottoman State, which was spread over a wide geographical area, had been heavily affected by epidemic diseases due to its location as well as political, commercial, social and cultural interactions. The Ottoman State made great efforts to combat these epidemic diseases that spread throughout the country. Tuberculosis also known as Phthisis is among these diseases that caused the deaths of thousands of people in the previous centuries both in the world and Anatolia and was finally taken under control with vaccine. In the study titled Dünyada Türberkükozun Tarihi (History of Tuberculosis in the World), is stated that the effects of tuberculosis in the Ottoman period were observed in those who got sick from tuberculosis in the Topkap1 Palace and Dolmabahçe Palace. The biggest interest on tuberculosis and rabies had been shown by Abdulhamit II. Robert Koch discovered tuberculosis bacillus in 1882, tuberculosis bacillus was shown in 1885 with sputum staining in Istanbul; Treatment of tuberculosis with tuberculin was tried in Germany in 1890. The same year, in Istanbul, Tuberculin was used for the treatment of tuberculosis as well.

The word verem (tuberculosis) is a medical term of Arabic origin and is defined in the dictionaries as "infectious, febrile illness caused by Koch bacillus, tuberculosis" which is located in any organ throughout the body, especially the lungs. There is detailed information about this subject in various medical texts. Many names have been given to tuberculosis disease. Consumption has been used because it kills people due to weight loss, the white death or white plague name was given due to the paleness of patients, and captain of the death name was given due to the number of death. The Romans named this disease phytisis, meaning wheezing and spitting out sputum with coughing. In Turkish, the most common expression for tuberculosis is ince hastallk (delicate disease). This expression was used by people for someone who has died from passionate love. In this case, "delicate disease" most probably was used to avoid the word tuberculosis. Apart from this, tuberculosis in our language is also called adı bellisiz (disease with no name), ince ağrl (delicate pain), and ince dert (delicate trouble).

In this study; Hüseyin Kâmî’s book Emrâz-ı Müzmine and Sâriyeden Verem: İbtidâsı, Edvârl, Sûreti Tevakkî and Tedâvîsi was examined. He wrote it using the pseudonym Kâşif Dehrî. The book was published by Sancakciyan in Istanbul in Hijri 1331 / Gregorian 1915 and has 42 pages. At the beginning of the work, under the title "Birkaç Söz (A Few Words)", the author writes that today, despite the progress of science, the number of victims of this chronic and lethal disease is increasing. Thousands of young people die every year due to this disease. Although doctors write too many books telling that tuberculosis is a contagious, preventable and healable disease, the disease does not hesitate to attack humanity with all its severity. Measures and precautions taken for epidemics such as plague and cholera are neglected for tuberculosis.

The author states that the difference between tuberculosis and other epidemics is that it is genetic and therefore passes through parents. Congresses and researches regarding tuberculosis' pandemic and its treatment have been carried out for a long time and various conclusions have been extracted. However, looking at the statistics, Europe alone has lost about 1.5 million of its population due to this disease. He explains the purpose of this work by saying: "That's the reason why I bring this information, compiled from French works about tuberculosis, to the reader's attention: so that the reader can benefit from it".

The work consists of the following sub-titles: What is Tuberculosis? (p. 6-9); Causes of tuberculosis spread (p. 9-13); The onset of tuberculosis (p. 13-16); Various symptoms at the beginning of the tuberculosis (p. 16-22); Susceptibility to tuberculosis (p. 22-26); Treatment methods of tuberculosis (p. 26-37); Nutrition of tuberculosis patients (p. 37-42).

The following can be concluded: Outbreaks have affected societies for centuries and caused many casualties. Examining the studies carried out on this topic, it is evident that the most important ones are in the field of medicine. In addition, this topic has also been the subject of fields like history of medicine, history, sociology, psychology, economics, international relations and even literature. The text discussed in this study is the work of Hüseyin Kâmî, who has written various novels about many topics, in which he shows his interest in social issues with the sensitivity of a literary person and artist. In this work, the author expresses his sadness for the deaths of thousands of people due to the tuberculosis epidemic and brings to the attention of the reader the importance of personal responsibility regarding the combat of tuberculosis. He also emphasizes the importance of fighting together against epidemics.

Keywords: Turkish language, Ottoman Turkish, Medical texts, Tuberculosis, Hüseyin Kâmî. 
Öz: Hastalık; organizmada birtakım değişikliklerin ortaya çıkmasıyla sağlığın bozulması durumudur. Tarihsel süreçte tarım öncesi avcılık ve toplayıcıkla uğraşan toplumlarda insanlar hayatlarını genellikle çevreyle ilgili sebeplerle ve av kazaları sonucu kaybetmiştir. Tarım toplumlarında ise hava, su, yiyecek ve vektörlerle (bit, sinek, kene, pire gibi asalak böcekler) bulaşan enfeksiyon hastalıkları yaygınlaşmış ve salgınlar (epidemi ve pandemi) çok sayıda insanın ölümüne yol açmıştır. Bu tür salgınlar ancak hastalığın aşısının bulunmasıyla kontrol altına alınabilmiştir. Bu hastalıklardan bir tanesi de verem, diğer adıyla tüberkülozdur. Verem kelimesi Arapça kökenli bir tıp terimi olup sözlüklerde vücutta herhangi bir organa, özellikle akciğerlere yerleşen Koch basilinin yol açtığı bulaşıcı, ateşli hastalık, tüberküloz şeklinde tanımlanmaktadır. Romalılar bu hastalığa, hırıltılı nefes alıp verme ve öksürükle balgam atma anlamındaki phytisis adını koymuşlardır. Türkçede ise verem için en çok kullanılan kelime ince hastalıktır.

Bu çalışmada Hüseyin Kâmî (takma adıyla Kâşif Dehrî)'nin Emrâz-ı Müzmine ve Sâriyeden Verem: Ibtidâsı, Edvârı, Sûret-i Tevakkî ve Tedâvîsi adlı eseri ele alınarak incelenmiştir. Eser, Hicrî 1331/Milâdî 1915 yılında İstanbul'da basılmış olup 42 sayfadır. Eser şu alt başlıklardan meydana gelmiştir: Verem Nedir?; Veremin Esbâb-ı Intişârı (Veremin yayılma sebepleri); Veremin İbtidâsı (Veremin başlangıcı); Veremin Eşkâl-i İbtidâiyyesi (Veremin başlangıcında görülen çeşitli rahatsızlılar); Vereme İstîdâd (Vereme yatkınlık); Veremin Sûret-i Tedâvîsi (Veremin tedavi şekli); Müteverrimlerin Sûret-i Tagaddîsi (Verem olan kişilerin beslenmesi).

Anahtar Kelimeler: Türk Dili, Osmanlı Türkçesi, Tıp metinleri, Verem, Hüseyin Kâmî.

\section{Giriş}

Beylikler döneminden başlamak üzere gerek çeviri gerek telif yoluyla pek çok tıp kitabı yazılmıştır. Bu eserler arasında özellikle 19. ve 20. yüzyılda Osmanlı Türkçesiyle yazılmış salgın hastalıkları (kolera, frengi, verem gibi) konu edinen metinler ayrı bir önem taşımaktadır. Bu metinlerden bazı örnekler verilebilir: Hekimbaşı Mustafa Behçet, Kolera Risâlesi (H. 1247/ M. 1801); Hekimbaşızâde Muhyiddin, Vâlideye İhtâr Yâhûd Kuş Palazı (H. 1316/ M. 1900); Mütercim Mahmûd Celâleddin Muhtar [Özden], Frengi ve İzdivâc (H. 1317/ M. 1899); Beyrut Sihhiye Müfettişi Doktor Nizâmeddin Bey, Difteriye Karşı Serum Tedâvîsi (H. 1312/ M. 1894); Dr. Besim Ömer, Çiçek Hastalığı ve Su Çiçeği (H. 1310/ M. 1892). Bu çalışmaya konu olan Emrâz-ı Müzmine ve Sâriyeden Verem: İbtidâsı, Edvârı, Sûret-i Tevakkî ve Tedâvîsi de Hüseyin Kâmî (müstear 'takma' adıyla Kâşif Dehrî) tarafindan kaleme alınmış vereme dair müstakil bir eserdir.

Hastalık; organizmada birtakım değişikliklerin ortaya çıkmasıyla sağlığın bozulması durumudur. Tarihsel süreçte tarım öncesi avcılık ve toplayıcılıkla uğraşan toplumlarda insanlar hayatlarını genellikle çevreyle ilgili sebeplerle ve av kazaları sonucu kaybetmiştir. Tarım toplumlarında ise hava, su, yiyecek ve vektörlerle (bit, sinek, kene, pire gibi asalak böcekler) bulaşan enfeksiyon hastalıkları yaygınlaşmış ve salgınlar (epidemi ve pandemi) çok sayıda insanın ölümüne yol açmıştır (Tekin, 2007: 28). Bu tür salgınlar ancak hastalığın aşısının bulunmasıyla kontrol altına alınabilmiştir. Tarihi insanlık tarihi kadar eski olan ve insan hayatını son derece olumsuz yönde etkileyen salgınlar pek çok araştırmanın da konusu olmuştur. Gerek tıp tarihi gerek genel tarih araştırmalarında bulaşıcı hastalıkların nerelere ve ne şekilde yayıldığı, salgınları önlemek için ne gibi tedbirlerin alındığı ve bunun siyasi, sosyolojik, psikolojik ve ekonomik sonuçları gibi konular ayrıntılı olarak ele alınmıştır.

Çok geniş bir coğrafi alana yayılmış olan Osmanlı Devleti de konumu itibarıly salgın hastalıkların etkisi altında kalmış; siyasi, ticari, sosyal ve kültürel iletişimler sonucunda da ülkeye yayılan bu salgınlarla mücadele için büyük bir gayret göstermiştir. Önceki yüzyıllarda gerek dünyada gerekse Anadolu'da binlerce kişinin ölümüne sebep olan, aşısının bulunmasıyla kontrol altına alınmış olan bu salgın hastalıklardan bir tanesi de verem, diğer bir ifadeyle tüberkülozdur. Osmanlı döneminde veremin etkisinin Topkapı Sarayı ve Dolmabahçe Sarayı'nda görüldüğü kayıtlardan anlaşılmaktadır. Mesela; III. Selim'in gözdesi Safinaz Hanım, II. Mahmud, I. Abdülhamit'in kalfası Nakşıdil, Tanzimat döneminde sadrazamlık yapmış olan Ali Paşa veremden (tüberküloz) veya 
akciğer vereminden vefat etmiştir. 1876 yılında tahta çıkan II. Abdülhamit, halk sağlığına büyük önem vermiş, 1882 yılında Robert Koch'un verem basilini bulmasından üç yıl sonra 'balgam boyama' ile verem basili tespiti metodunun İstanbul'da uygulanmasını sağlamıştır. Almanya'da 1890 yılında Tüberkülin ile veremin tedavisi denenmiş ve aynı yıl İstanbul'da tüberkülin veremli hastaların tedavisinde kullanılmıştır (Barış, 2010: 4).

Verem kelimesi, Arapça kökenli bir tıp terimi olup sözlüklerde genel olarak, vücutta herhangi bir organa, özellikle akciğerlere yerleşen Koch basilinin yol açtığı bulaşıcı, ateşli hastalık, tüberküloz şeklinde tanımlanmaktadır. Bu konuda çeşitli dönemlerde kaleme alınan tıp metinlerinde de ayrıntılı bilgiler mevcuttur. Verem hastalığına birçok isim verilmiştir. İnsanları eriterek öldürdüğü için tüketim hastalı̆̆ anlamındaki consumption, insanları soldurarak yok ettiği için beyaz ölüm veya beyaz veba ve pek çok insanın yaşamını sonlandırdığı için de ölümün kaptanı (captain of the death) diye anılırdı. Romalılar bu hastalığa, hırıltılı nefes alıp verme ve öksürükle balgam atma anlamındaki phytisis adını koydular (Barış, 2010: 1).

Türkçenin ağızlarında ise verem için pek çok kelime kullanılmaktadır: adı bellisiz, akarca, gelincik, gözel hastalık, gözelleme/güzelleme, güzel ă̆rl, ince ağrl, ince hastalık, ince dert, ince illeti, kel hastalık, kurudan, öpke avruu, sütçe, yılancık gibi. Aşk, dert ve verem arasında bir bağlantı olduğunu söylemek yanlış olmayacaktır. Türkçede "çok üzmek, dert sahibi yapmak" anlamında verem etmek sıkça kullanılır. Halk arasında sevda çekip ölene de "ince hastalıktan öldü" derlermiş. Burada, sevdadan kaynaklanan ince hastalık da verem olmalıdır (Koç, 2010: 79). Ayrıca, Tanzimat'la beraber romantizmin büyülü havasını üstünde taşıyan ediplerimizin eserlerinde görülen genç kız tiplerinin birçoğunda vereme rastlarız. Ancak, bu eserlerde hassas ve ince ruhlu insanlara has bir meziyet gibi çıkar karşımıza ve övünç vesilesi olur (Yalçın, 1981: 23). Nitekim, bu metnin yazarı Hüseyin Kâmî'nin kaleme aldığı 186 sayfa olarak yayımlanmış Müteverrime (1320) romanı da müteverrime (vereme yakalanmış) Râbia'nın hayatına dayanır. Bu romanda verem bir aşk hastalığı olarak karşımıza çıkar: Râbia, Bedi'ye karşı ilgi duyar. Ancak, Bedi’ye ablasının kızı Nermîn de ilgi duymaktadır. Aşkında fedâkârlık yapan ve daha sonra Bedi'nin arkadaşı Avnî ile evlenen Râbia üzüntüsünden dönemin hastalığı vereme yakalanır.

Bu çalışmada müellif Hüseyin Kâmî (müstear 'takma' adıyla Kâşif Dehrî)'nin Emrâz-ı Müzmine ve Sâriyeden Verem: İbtidâsı, Edvârı, Sûret-i Tevakkî ve Tedâvîsi adlı eseri ele alınarak incelenmiştir. Çalışma, Girişs (Hüseyin Kâmî'nin Eserleri ve metin hakkında bilgi), Metin, Sözlük ve Sonuç kısımlarından oluşmaktadır.

\section{Hüseyin Kâmî’nin Eserleri ve Emrâz-ı Müzmine ve Sâriyeden Verem: İbtidâsı, Edvârı, Sûret-i Tevakkî ve Tedâvîsi}

Eserin müellifinin hayatı ve eserleri konusunda birçok çalışma yapılmıştır. Yapılan bu çalışmaları bir araya toplayan İlyas Kayaokay, çalışmasında Hüseyin Kâmî’nin, K. D. rumuzuyla eserler verdiğini belirterek K. D. rumuzuyla üç, Kâşif Dehrî adıyla bastırdığı dokuz eserinin olduğunu ifade etmiştir. Ayrıca şu bilgiler de verilmektedir: "Bu eserlerin tamamı Özege Katalogu'nda kayıtlıdır. Burada Kâşif Dehrî’nin adının yanına parantez içinde [Hüseyin Kâmî] yazılmış olduğu görülür. Akademik çalışmalarda, özellikle Son Asır Türk Şairleri referans alındığı için müellif hakkında verilen bilgiler eksik kalmıştır. Hüseyin Kâmî (Kâşif Dehrî)'nin tespit edebildiğimiz eserleri şunlardır: Nutk-ı Siyâsî (1326), Dîvânçe-i Dehrî (1327), Kâbus Iç̧inde (1328), Mâtem Tülleri (1328), Mecnûne (1328), Müteverrime (1328), Üvey Valide (1328), Kapitülasyonlar (1329), Zarâfet-i Nisvân (y.y), Emrâz-ı Müzmine ve Sâriyeden Verem (1331), Muhabbet İzdivâc Mektûbları (1331), Mazlûme (1332), Paris Muhâsarası (1331), Mayıs Ayında Doğanlar Mes'ûd ve Bahtiyâr Olmak İçin Ne Yapmall, Neye Teşebbüs ve Neden Ihtirâz Etmeli (1331) (Kayaokay, 2019: 309-310). Bu eserlerin yanında Hüseyin Kâmî'nin döneminde çıkan birçok dergide takma adlarla yazılar yazdığı bilinmektedir. En çok da Baha Tevfik'in dergilerinde takma isimlerle yazılar kaleme 
alır. Eşek, Yuha, Kibar, Malum mizah mecmularında Dehrî, Donkişot, Baba, Tırnağ Karıncall, Sudan Geçmez müstear (takma) adlarıyla hicivler neşretmiştir (Sarıca, 2012: 13).

Üzerinde çalışılan metinde müellif Kâşif Dehrî takma adıyla kayıtlıdır. Eser, Hicrî 1331/Milâdî 1915 yılında İstanbul'da Sancakcıyan Matbaası'nda basılmış olup 42 sayfadır. Eserde ilk olarak "Birkaç Söz" başlığı altında özetle şu bilgiler verilmektedir: Bugün, bilimin ilerlemesi, gelişmesine rağmen bu müzmin (kronik) ve mühlik (öldürücü) hastalığın kurbanları gittikçe artmaktadır. Her geçen yıl bu hastalık nedeniyle binlerce genç ölüp gitmektedir. Doktorlar veremin bulaşıc1, korunulabilen ve şifa bulunabilen bir hastalık olduğu konusunda ciltlerle kitaplar yazdığı hâlde hastalık bütün şiddetiyle yine insanlığa saldırmaktan geri durmuyor. Veba, kolera gibi salgın hastalıklar konusunda gösterilen özen ve alınan tedbirler, verem konusunda ise ihmal ediliyor.

Yazar, veremin diğer salgın hastalıklardan bir farkının da irsî olması ve dolayısıyla anne veya babadan evlada geçmesi olduğunu belirtmektedir. Öteden beri evrensel bir salgın hastalık şeklini alan vereme çare konusunda araştırmalar yapılmakta ve bu araştırmalar sonucunda da çeşitli bilgiler verilmektedir. Ancak istatistiklere bakıldığında yalnız Avrupa 1.5 milyona yakın nüfusunu bu hastalıktan kaybetmiştir. İşte bu yüzden, faydalı olmak adına, verem konusunda yazılmış Fransızca eserlerden derlenen bilgileri okuyucuların dikkatine sunuyorum, diyerek eseri yazış sebebini de açıklamaktadır.

Eser şu bölümlerden meydana gelmektedir: Verem Nedir? (s. 6-9); Veremin Esbâb-ı İntişârı (Veremin yayılma sebepleri) (9-13); Veremin İbtidâsı (Veremin başlangıcı) (13-16); Veremin Eşkâli İbtidâiyyesi (Veremin başlangıcında görülen çeşitli rahatsızlıklar) (16-22); Vereme İstîdâd (Vereme yatkınlık) (22-26); Veremin Sûret-i Tedâvîsi (Veremin tedavi şekli) (26-37); Müteverrimlerin Sûreti Tagaddîsi (Verem olan kişilerin beslenmesi) (37-42).

Verem Nedir? başlıklı birinci bölümde yazar veremin tanımını yaparak zayıf bünyelerde "koch basili" denilen bir mikrobun vücuda yerleşmesi ve çoğalması sonucu hastalığın meydana geldiğini belirtir.

Veremin Esbâb-ı İntişârı başlıklı ikinci bölümde ise hastalığın hem bulaşıcı hem de veraset (kalıtım) yoluyla ortaya çıkan bir hastalık olduğunu ifade eder. Vereme sebebiyet veren durumlar arasında ise fazla mesai, rutubet, iştahsızlık, 1şıksızlık başta gelmektedir. Verem mikropları her yerde bulunabilir: Evlerde, yenilen gidalarda, giysilerde, arabalarda...

Veremin İbtidâsı başlığı altında veremin başlangıcı ve hangi hastalıkların veremi daha çok tetiklediği üzerinde durulur. Kişinin bedenindeki ve bünyesindeki "zaâfiyet" vereme zemin hazırlar. Ayrıca, alkol bağımlılığı, şeker hastalığı, frengi de vereme sebebiyet vermektedir.

Veremin Eşkâl-i İbtidâiyye'sinde veremin ne sûretle ne şekillerde bulaştığı ve veremli kişinin vücudunda ne gibi belirtilerin olduğu üzerinde durulur. Hastanın ateşi yükselir, kalp ve nabız atışları hızlanır. Susuzluk, halsizlik, hararet ve hazımsızlık başlar. Yavaş yavaş hastanın siması değişir. Şakaklarda, gözlerin etrafında, yanaklarda bir çukurluk meydana gelir. Kuru, kesik öksürüklerle seste bir kısıklık ve boğukluk vukû bulur.

Vereme İstîdâd ve Veremin Sûret-i Tedâvîsi bölümlerinde hastalığa yatkınlık, hastalıkla ilgili tedavi yöntemleri açıklanır. Tedavide en önemli husus doktorlardır. Doktor da güvenilen ve ustalığından emin olunan bir doktor olmalıdır. Bu bölümde yanlış bir tedavi yöntemi olarak korse giydirilen bir hastanın nasıl kısa sürede ebediyete intikal ettiği yaşanmış bir vakayla anlatılır. Müellif, hastalara tavsiyelerde de bulunur: Şehirlerden kaçmalı, kalabalıktan uzak yaşamalı, kırların temiz havası teneffüs edilmelidir. Diğer bir önemli tavsiye de "kalp huzuru" içinde hayat idame ettirilmelidir.

Son bölüm olan Müteverrimlerin Sûret-i Tagaddîsi'nde ise verem hastalarının nasıl beslenmesi gerektiği üzerinde durulur. Beyaz ekmek sadece nişastadan ibaret olduğu için dikkatle 
tüketilmelidir. Buğday, pirinç, mısır faydalı hububattır. Pirincin pilav olarak tercih edilmesi gerekir. Yumurta gıdaların en mükemmelidir. Yoğurt ve sütten hangisinin tüketileceği doktora bağlidır. Veremlilerin taze sebze yerine kuru sebzeye ağırlık vermesi gerekir. Nohut, mercimek, fasulye gibi. "Saf" olmak şartıyla su en iyi içecektir.

Metin

\section{Emrâz-ı Müzmine ve Sâriyeden Verem: İbtidâsı, Edvârı, Sûret-i Tevakkî ve Tedâvîsi}

\section{[6] Verem Nedir?}

Verem, bugün, bütün hey'et-i ictimâiyye-i beşeriyyenin umûmî ve ictimâî bir hastalığıdır ki küre-i arz üzerindeki aded-i musâbîni pek mühim bir yekûn hâsıl eylediği gibi kurbânları da senevî mevcûdât-1 arzın altıda birini buluyor. Bu müzmin hastalık, emrâz-1 kadîmeden olup öteden beri bütün cihân etibbâsını müteselsilen işgâl eylemiş ve fakat fennin terakkîsi nisbetinde dâire-i tahrîbâtını tevsî‘ ile bu bâbda sebk eden mesâî-i vafîreye karşı âdetâ cidâl-gâha atılmıştır.

Verem, dâimâ hasta veya za‘îf vücûdlarda "koch basili" denilen bir mikrobun tekessür ve neşv ü nemâsından husûle gelir. Beden-i insânîde mevcûd mikroplar ikiye münkasımdır: Bir kısmı hayât-1 beşer için fâideli, diğer [7] kısmı da muzırdır ki bunların kâffesini göz ile görebilmek mümkün olamayıp mutlakâ kuvvetli hurde-bînlere ihtiyâc vardır. Bu "basil" de hurde-bîn ile görülebilip gâyet ufak, gayr-1 muntazam bir çomak şeklinde müşâhede olunur.

İşte bu muzır mikrobun en mühim hâssası senelerce şiddet-i tenebbüt ve semmiyyetini muhâfaza ile bütün mesâîye rağmen kendini sühûletle tahrîb ettirmemesidir. Bunun içindir ki bu marazın mübtelâları uzun bir mübâreze-i tıbbiyyeye arz-1 iftikâr ediyor. Bu mikroplar vücûd-1 insânîde yaşayarak kendilerine mahsûs semler ifrâz ederler ki işte bu zehir, hem bulunduğu yeri tesmîm ve hem de ensâc ve mevâdd-1 uzviyyeyi tahrîb eder.

Bu mikrop her vâsıta ile vücûda dâhil olabilir. Bir kere cildden içeri girince hemân ifrâzât-1 zehr-nâkine başlar. Fi'l-hakîka vücûdda bunların te'sîr-i sem-dârını tahdîd ve ta'kîm için müdâfaât vukû‘ bulur. Ezcümle vücûddaki ufacık anâsır, hücrecikler, tecezzî ve tekessür ve damarlar tevessü‘, ve kandaki küreyvât-1 beyzâ damardan hârice atılarak mezkûr basilin zehirlediği mahallin etrâfında tecemmu' ederek orasını tahdîden bir mıntıka teşkîl eyler. Bu mıntıka-i mahdûde bir darı taneciği gibi şekil ahz eyler ki buna ta "bîr-i fennîsiyle "hubeyb-i derenî" ve lisân-1 avâmda "verem habbeciği" veyâ "tüberkül" ttlâk olunur. [8] Bunun üzerine bedendeki mikroplarla bir muhâceme başlar. Eğer basilin zehri pek şedîd ve müessir ise etrâfını ihâta etmiş olan hudûdu yumuşatır, orası çıbanlaşır ve aradan kayarak etrâfa dağılır, tahrîbâtına, tesmîmâtına germî verir. Bu, ancak o mukâvim ve müdâfi‘ hücreciklerin kuvve-i hayâtiyyesinin adem-i kifâyeti hâlinde vâki' olabilir.

Eğer verem mikropları gayr-1 müessir ve daha doğrusu intân daha mebde'inde ise bu mukâvim ve müdâfi' mikroplar basilin etrâfinda ta'azzuv ederek bunun bir daha o mahalden çıkamamasını te'mîn eyler. Bu hâlde vücûddaki kuvâ-yı mukâveme-i tabîiyye ne derece faâl, kuvvei hayâtiyyeye mâlik ve kendi muhâcimlerini itlâfa müheyyâ ve tahdîd-i tahrîbâtına muktedir ise o nisbette hayât-1 beşer bu marazın dendân-1 mühlikinden tahlîs-i girîbân eyler.

\section{[9] Veremin Esbâb-ı İntişârı}

Veremin sârî olduğu mâlûm-1 enâmdır. Bu hâlde insân ya sirâyet veya verâset ile teverrüm eder. İfrât-1 mesâî, ziyâsızlık, rutûbet bu husûsta en birinci âmildir. Basil pek muhtelif sûretle vücûda dâhil olabilir. Gışâ-yı muhâtîlerde ehemmiyet vermediğimiz bir yara bu mikrobun vücûda dâhil olabilmesini tesrî́ ‘ ve teshîl eyliyor ve bir def'ada dâhil oldu mu artık dâimâ bedendeki nâfi ‘ mikroplara galebe ile uğraşıyor ve sıhhatin en ufak rahatsızlığından istifâdeye şitâbân oluyor.

Bu mikroplar her yerde mevcûddur. Sokaklarda, arabalarda, şimendiferlerde, bütün kâbil-i ekûl mevâdda müteverrim olan eşhâsın ikâmetgâhlarında ve elbiselerinde mebzûlen bulunur. Hattâ 
hastahâneler bile bu mikroplardan kurtulamamıştır. [10] Akciğer vereminin ale'l-ekser sirâyetle vukû‘ bulduğu etibbâca mâlûm-1 hakâyık-1 bârizedendir.

Hayvânât ve et'ime vâsıtasıyla sirâyet pek azdır. Çünkü mikrobun em'âdan başlaması muktezîdir ki bu düşvârdır. Hattâ balgamını yutan bir hastanın bile em‘â veremine uğradığı enderdir. Ancak bu marazın vâsi` mikyâstaki sebeb-i intişârı balgamdır. Herkes, her tarafa tükürüyor. Bâ-husûs şarkta bu hâl ahvâl-i tabîiyyeden görülüyor. Sokaklarda kuruyan bu balgamlar, toz olarak teneffüs ediliyor. Bu zehirli mikrop bu sûretle âzâ-yı bedene dâhil oluyor. Hava borusu ile akciğerlere vâsıl oluyor. Orada mecmûalar husûle getiriyor, hastalık tedrîcen büyüyor. Avrupa'nın bazı şehirlerinde tükürmek kat'iyyen memnû' olup bunun mütecâsirleri hakkında muhtelif cezâlar tertîb ve hattâ 25 Franga kadar cezâ-yı nakdîler bile istîfâ edilmektedir.

Sokaklara ta'lîk edilen levhalar bu memnûiyyeti i'lâm ve i'lân içindir. Sirâyetin tahakkuku mâlûm olunca verâsetin kabûlü de tabiîdir. Etibbâ-yı kadîme verâseti vâsita-i intikâl olmak üzere kabûl eylemişlerse de asr-1 ahîr etibbâsı az çok şüphe ve tereddüde boğulmuştur. Ancak emrâz-1 sâireye mübtelâ ebeveynden hâsıl olan evlâdın maraz-1 mevrûsla ma'lûl [11] olduğu sâbit olduğuna ve bu hakîkatin cümleten kabûl edildiğine nazaran veremin de sübût-1 intikâline kâil olmak muktezîdir. Bu bâbda icrâ edilen tecâribde basillerin hem meşîme-i mâderde ve hem de cenînde bulunduğu tamâmen sâbit olmuştur. Ebeveynin her müzmin hastalığı, evlâdı üzerinde doğrudan doğruya değilse bile vereme karşı bir istîdâd husûlünü intâc ediyor. Husûsiyle dâ'-i küûl, frengi, seretân yâhûd illet-i asabiyye ile musâb olan ebeveynin mahsûl-i hayâtı dâimâ verem istîdâdını hâiz bulunuyor. İstîdâd-1 irsiyyedeki ihtimâl-i sirâyet daha ziyâdedir. Müteverrim bir vâlideden tevellüd eden nevzâdın göbeğinden alınan kan bir hayvâna şırınga edilecek ve ba'dehu hayvân öldürülecek olursa ensâc-1 muhtelifesinde verem habbecikleri bulunur.

Ebeveynin evlâd üzerindeki te'sîri mutlaktır. Bu bâbdaki tecrübeler dâimâ bunu isbât edegelmiştir. Bi't-tecrübe tavuk yumurtaları yılan ağularıyla zehirlenecek olursa bunlardan çıkan piliçlerin âzâ-yı bedeniyye-i hâriciyyesinden birinin noksâniyeti görülüyor. Bu hâlde intânî zehirlenmiş olan bir babanın tesemmümü evlâdına da intikâl eyliyor. İnsânlar iki sûretle tesemmüm eder: Biri ilâç hâlinde vücûda ilkâ edilir: arsenik gibi. Diğeri de keyf veya et'ime sûretinde mi'de vâsıtasıyla alınır: [12] küûl gibi. İște bunların vücûdda hâsıl eylediği sümûmun ve mevâdd-1 semmiyyenin tekessürü, bedenin mukâvemetini tenkîs ve bu muzır ve zehr-nâk maddeler vücûdu tahrîb eyliyor. Telef olmuş basiller ber-hayât tohumlar gibi tevlîd-i emrâza kâbiliyetdârdırlar, ancak tenebbüt edemez, üremez, fakat birçok zamânlar vücûdda pâyidâr kalan bu lâşeler de sem-dâr olup verem hâs1l edebilirler. Maamâfîh istîdâd "maraz-1 farazî"dir. Bundan kat'iyyen havf etmeyip intizâm-1 hayâtiyyeye îtinâ-kâr bulunmalıdır.

\section{[13] Veremin İbtidâsı}

Veremin başlangıcını za'fiyyet ve sefâlet-i bedeniyyede aramalıdır. Hakâyık-1 müsebbetedendir ki bu basiller vücûd-1 insânîde ârâz ve âsâr-1 teverrüm göstermeksizin de bulunabilir. Bunlar nefes borusuna ve hattâ nihâyetlerine kadar sokulur ve bunu ihâta eden gışânın üzerinde temekkün ederler ve hattâ ufak bir nezle ile bu gışâ-yı muhâtî zedelenince mikroplar bundan bilâ-istifâde lenfa vâsitasıyla oraların ukde-i lenfaviyyesine kadar nüfûz eylerler ve oracıkta müheyyâ-yı hücûm bir vaziyetle istirâhat-nişîn olurlar. Ancak bu sükûnet istîdâd-ı habâislerini sektedâr edemez. Ufak bir ârıza te'sîriyle vücûdun za'îf ve zebûn kaldığı zamânda birdenbire faâliyete başlayarak icrâ-yı vazîfeye atılırlar. İşte veremin ibtidâsı ve ibtidârı böyledir.

Vücûdda hâsıl olan berecikler, zedeler dâimâ verem basillerine karâr-kâr olabilir ve kanın cereyânına mâni' olan bu yaralarda tahaffuz eden muzır mikroplar ilk firsatta içeri dâhil olarak îfây1 vazîfeye müterakkibdirler.

[14] Dâ'-i küûl ile teverrüm arasındaki münâsebet, mukârebet derecesindedir. Etibbânın tedkîkât-1 amîkalarına nazaran küûlün vücûddaki tahrîbâtı teverrüme istîdâd hâsıl ediyor. Mâdâm ki 
koch basilleri vücûdun her türlü za'fiyyet ve temâruzundan istifâdeye şitâbân oluyor, bu hâlde küûlün ilkâ eylediği te'sîrât da bu istifâdeye meydân açıyor demektir. Küûl, bütün âzâ-yı hazmiyyeyi kavuruyor, yakıyor. Dâ'-i küûlün hâsıl eylediği teverrümün ibtidâsında ale'l-ekser tükürülür. Akciğerlerin ve damarların vezâifindeki bozukluk da arazı teşdîd ile verem habbecikleri karaciğeri istilâ eder. Esâsen bütün sem-dâr ve muzır mikroplara süzgeç hidmetini gören bu uzvun tahrîbi vücûdu yavaş yavaş mezâr-1 ademe sürükler.

Şeker hastalığı da teverrümü intâc eder. Bunda da karaciğerin vazîfesine ârız olan bozukluk sebeptir. Muzır mikropların kana geçmesini men', kanın tasfiye ameliyyesini hüsn-i îfâ etmeyen bu uzvun teessür ve adem-i tevâzünü verem basillerinin neşv ü nemâ ve sühûletle tenebbütüne hidmet eder ve bi'n-netîce ademi mûcib olur.

Frenginin veremle münâsebeti kat'îdir. Frengi hadd-i zâtında insanı za'îf düşürüp bedenin mukâvemetini tenkîs ve hattâ mahv eder. Frengililer vereme dûçâr olursa hastalık gayr-1 me'mûl bir sâat seyr ile insânı esîr-i memât eyler. Bunun için frengililer [15] vereme karşı son derece müteyakkız bulunmalıdırlar. Frengi dilde, bademciklerde, nefes borularında, hançerelerde, ciğerlerde yaralar hâsıl edecek olursa bunlar verem habbeciklerine açık kapı hidmetini îfâ eylerler. İltihâb-1 kasabât, kızamık, nezle-i müstevliye, boğmaca öksürügü gibi hastalıklar verem habbeciklerini kabûle istîdâd hâsıl eyler. Bütün bu emrâzın te'sîrâtı dâimâ akciğerlere musallattır. Buradaki gışâ-yı muhâtînin hafîf bir sûrette zedelenmesi koch basillerinin dâhil-i bedene saldırmasını mûcib olur. Zâtü'l-cenbin eskimesi mutlakâ veremi intâc eyler.

\section{[16] Veremin Eşkâl-i İbtidâiyyesi}

Ahvâl-i zâhiriyyesi îtibâriyle sükûnet-engîz görünerek hayât-1 beşeriyyeyi kemiren bu maraz-1 vahîmin ne sûretle ve ne şekillerde bulaştığını anlayalım.

Vücûddaki harâret-i tabîiyyenin tezâyüd ve tereffu' 1 , zıyâ'-1 harâret-i bedeniyyeyi ve vazîfei ifrâgdaki adem-i kifâye ve noksânîyi mûcib olur. İfrâgât ve ifrâzâtında adem-i kifâyeti görülen vücûd bi’t-tabî‘ birç̧ok mevâdd-ı mesmûmeyi def' edemediğinden sem-âlûde kalır. Ve bu hâlde bütün cihâz-1 dâhiliyyenin vazîfesi muhtel bir tarzda cereyân eyler. Harâret-i tabîiyye-i beşer, koltuk altında 36.8 ve ağızda 37.4 derece olup 37.8'den fazlası ahvâl-i maraziyyeyi ve hummâyı gösterir. Hummâ esnâsında nabzın vurması da fazlalaşır. Mâlûmdur ki kalp dakîkada 64 ile 68 arasında takallüs edecek yerde aded-i darabât 80 ve hattâ 100 'e kadar çıkar.

[17] Teverrümde hummâ dâim ve fakat geçicidir. Ale'l-ekser akşam üzerleri ve gece yemekten sonra harâret kendini gösterir. Atşân, halsizlik, baş ağırlığı harâret-i bedeniyyenin tebeddül ve tereffu' 1 veremin evsâf-1 mahsûsesinden addolunabilir. Teverrüm hazımsızlıkla başlar, bu mes'elenin ehemmiyeti pek büyüktür. Hattâ bazı esâtize-i etibbâya "ale'l-ekser teverrüm hazımsızlıkla başlar ve bununla nihâyet bulur" bile dedirtmiştir. Binâenaleyh hazımsızlık mes'elesine ehemmiyet vererek bunu biraz teşrîh edelim:

Tagaddî de bir hıfz-1 sıhhate tâbi ‘dir ve hattâ rûhîdir. Hıfz-1 sıhhat-i agdiye çocuğun rahm-1 mâderden sukûtu ânından ibtidâr ile bütün müddet-i hayâtiyyesinde tâbi ‘ olduğu en mühim bir program olmalıdır. Çocukların igtidâsına ehemmiyet vermeyen vâlideler yavrularını her türlü emrâza kendi elleriyle, kendi dikkatsizlikleriyle daha çocukluğunda nâmzed etmiş addolunurlar. Sû'-i igtidâ dolayısıyla zamân-1 tufûliyyetinde ishâller, gaseyânlar, sıskalıklara mukâvemet etmiş olan etfâl ileride sıraca ve lenfavîlik, verem gibi emrâz-1 vahîmeye müstaid ve nâmzeddirler. Vakitsiz igtidâ, şiddetli heyecânlar, tabîi hazımsızlıklar tevlîd eder ve hazımsızlık kansızlığı, kansızlık da za'fiyyeti intâc eyler. Bu za'fiyyet ve nâ-tüvânî üzerine istîdâdât-1 irsiyye ve emrâz-1 sâriyeden birçoklarına [18] beden mukâvemet edemeyerek sem-dâr mikroplar en mühim uzuvlar üzerinde karargâh kurarak hücûm tertîbâtına koyulurlar. 
Gençlerin âkil ve bâliğ oldukları zamânlardaki kansızlıkları, hazım ve aybaşı bozuklukları şâyân-1 dikkattir. Bunların tedâvîsine ehemmiyet verilmelidir. Sinn-i bülûğ ve kemâle eren genç kızlar bu esnâlarda birkaç seneler soluk ve kansız olurlar. Hattâ içlerinde yanakları kıpkırmızı olanları da bulunursa da buna rağmen kansızlıkları da vardır. Eğer dermânsızlık görünürse dikkat edilmelidir. Kızlardaki halecânlar, nefes tıkanmaları mühimdir. Teverrümün ibtidâsında âdet-i şehriyye tedrîcen tahavvül eyler. İbtidâ âdetin rengi değişip beyaz bir hâle gelir ve nihâyet bütün bütün kesilir. Bu inkıtâ'1n cihâz-1 teneffüsiyye ve kan üzerinde ehemmiyeti çoktur. Âdetin kesilmesi hastanın marazını teşhîs eyler. Bu teverrüme delâlettir. Sâir emrâz, hevl-nâk bile olsa âdetin intizâmını ihlâl etmez. Teverrümde âdetin inkıtâ' 1 hastalığı gösterdiği gibi bunun intizâmının avdeti de ancak hastalığın zevâline mütevakkıftır. Müteverrimelerde seyelân-1 ebyaz da çokçadır. Bunlar hep nişân-1 felâkettir.

Yorgunluk, iştigâlde ifrât, ziyâsızlık, tahavvülât-1 hevâiyye hep igtidâ-yı bedeni sarsar. Emrâz-1 ma'dûdeden başka ekdâr da bedenin faâliyet-i hayâtiyyesine sû'-i te'sîr eder. Ekdâr, iştahsızlığı, [19] sinir zayıflığını tevlîd ile bi'n-netîce cihâz-1 hazmiyyenin faâliyetini tenkîs eder, hazımsızlık meydana gelir. İşte bu hâlin devâmı bütün vücûdu en müzmin hastalıkların mev'id-i telâkîsi hâline getirir. Ağızda lezzet kalmaz, gaseyânlar, su'âli müteâkib kaylar zuhûr eyler. Öksürüğü müteâkib gaseyân, veremin başlıca alâmet-i mümeyyizesindendir. Mak'adda çıkan çıbanlar ve nâsûrlar bazı etibbâca alâmet-i sâbite-i teverrümden olduğu gibi zâten akciğer veremi ile mak'ad nâsûrı arasındaki münâsebet bütün doktorlarca mâlûm ve müsellemdir.

Teverrümde "zayıflama" gâyet batî olup muntazaman fazlalaşır. İbtidâ sîmâ ve sîneden başlar, şakaklarda, gözlerin etrâfında, yanaklarda çukurlar hâsıl eyler. Bu za'fiyyet bütün ensice-i vücûdiyyenin mikroplarla ağır ağır zehirlenmesinden mütevelliddir ki bilâhare hazmın kesb-i batâet etmesini mûcib olur.

Usret-i teneffüs, nabzın bozukluğu akciğerin deverân-1 demine halel târî olduğunu gösterir. Lenfa bezlerinin şişmeleri de arazın vücûduna delâlet eyler ki koltuk altında ve kasıklarda hâsıl olan şişkinlikleri nazar-1 dikkatten dûr tutmamalıdır. Bazen soğuk almak netîcesi olarak bel ağrıs1 hissedilir, bu ağrı âzâ-yı hâriciyye-i bedeniyyede kırmızı düğme gibi çıbanlar çıkarak ve her çıbanın yan tarafında mâyi` ile memlû bir kabarcık hâsıl olmasından ileri gelip öksürükle başlar.

[20] Cihâz-1 teneffüsiyye için soğuk algınlığı hastalığa sebeptir. Maamâfîh soğuk hava akciğerler için zararlı değildir fakat cildin üzerine musâdif sinirleri kamçılayarak damarları büzüyor ve dâhil-i bedendeki damarlar tevessü ' ederek kan oralara yayılıyor. Kanın dâhile hücûmundaki tehlike oldukça ehemmiyetlidir. Ale'l-ekser bu mes'ele kış günleri el üstlerinde gözle görülüyor. Soğuk havaya mârûz kalan elin sathı ibtidâ takallüs ediyor, rengini gâib eyliyor ve fakat bu soğuk rüzgâr devâm ettikçe bilâhare evvelki renksizlik yerine bir kırmızılık geliyor. El üzerindeki damarlar şişiyor, binâenaleyh bu damarları şişiren kan soğuyor ba'dehu cereyânla dâhilî damarlara yayılıyor. Bunun netîcesi sinirlere taab veriyor ve tehlike de bundan münbais oluyor. Soğuk, ellerimizin üzerinde çatlaklar hâsıl eylediği gibi beden-i dâhilîdeki iç derilerimize de icrâ-yı te'sîr ile gögüs nezleleri gibi hastalıklar tevlîd ediyor ve bedendeki muzır mikropların bundan istifâdesini teshîl eyliyor.

Sadânın tagayyürâtı da hastalığın vücûduna delâlettir. Hele ara sıra ses kısıklığı, perdelenmesi, boğuklaşması ve birkaç günler bu hâlde devâm ile ba'dehu hâl-i tabîiyyesini bulması gırtlağa kadar uzanan sinirlerin iltihâbına alâmet olup bâis-i endîşe ve takayyüd olmalıdır. [21] Veremin avâm-1 nâsa kadar mâlûm olan en mühim illeti öksürüktür. Hattâ etibbâ bile hastasında ibtidâ bunu arar. Veremlerde öksürük kuru ve kesiktir.

"Kan tükürme" keyfiyyeti de veremin arazı olmak üzere öksürük kadar taammüm etmiştir. Fi'l-hakîka hastanın tükürüğünde kan bulunması verem arazından olmakla berâber gırtlak nezlesi, damar hastalığı, hâmilelik, böbrek hastalıkları, kalp illetleri gibi emrâz-1 muhtelifeden de münbais olabilir. Daha garîbi şurasıdır ki hastalığın bidâyetinde görülen bu kan damlası hastaya zarardan 
ziyâde fâide bahşeder. Balgamında kan bulunan hastaların kan tükürmeyenlerden ziyâde hastalığa mukâvemet ettikleri ve daha ziyâde muammer oldukları öteden beri sâbit olmuştur ve etibbâca kabûl edilmiş hakâyık-1 mâkûsedendir. Ciğerler bu sûretle kandaki mevâdd-1 muzırra ve mesmûmenin bir kısm-1 âzamını hârice def ${ }^{*}$ ve tard ederek igtidâ-yı tabîilerini faâliyete getiriyorlar. Bunlar hep kandaki müfîd mevâddın muzır mikroplarla tehâcümünü gösteriyor.

\section{[22] Vereme İstîdâd}

Evvelâ verem ile vereme istîdâd arasında çok farklar vardır. Verem için şifâ-pezîrdir dersek vereme istîdâd için de verem olmaz kat'iyyetini verebiliriz. Ancak bu istîdâdı vaktiyle anlayıp tedâbîr-i sıhhiyyeye mürâcaat şartıyla. Bunun için bu istîdâdı tevlîd eden ârâzın âsâr ve alâimini burada muhtasaran beyânı fâideden hâlî görmem.

Verem istîdâdı ale'l-ekser nârin, nahîf vücûdlardadır. Bunların cildi rakîk, biraz etli ve fakat c1lızca, hilkat-i vücûdiyye çelimsiz ve mukâvemetsiz, sîne uzunca ve darcadır. Vücûdu ön tarafa mütemâyil, cebhe fırlak, kulakların zahrı kaba ve kabarıkçadır. [23] Gerek alnında ve gerek ellerinin üzerindeki damarlar ince ve mâvimsi olup gözle kâbil-i tefrîktir. Saçlar ipek gibi ince olup sert ve yatıktır. Gözler iri, muntazam, süzük, parlak ve azıcık derincedir. Göz bebeğinin büyüklüğü nisbetinde akı da mâvimtıraktır. Göz bebekleri hâlet-i kuvânın en hâd bir barometresi olduğundan derin bir za'fiyyet, fakrü'd-dem, cümle-i asabiyyedeki adem-i faâliyyet bunları sûret-i dâimede tevsî‘ eder. Nazarlar tatlıdır.

Ezmine-i kadîmede bile alâmet-i teverrüm, ensice-i vechiyyenin sarılığı ile göz aklarındaki ince kan damarlarının ve elmacıkların kırmızılığı idi. Bu alâim-i gayr-i tabîiyye kadınlarda daha ziyâde ayan ve zâhirdir. Etfâlde enderdir. Bu kırmızılık yalnız bir yanakta ise merzâ o tarafın ciğerinde taharrî etmelidir. Bu alâmet, etibbânın mürâcaat eylediği göğüs dinlemek veya vurmak gibi hâlât ile istinbât-1 illetten üç dört ay mukaddem âşikâr ve bedîdâr olur. Yanaklar çukur, müsellesü'l şekl, tatlı ve hazîn bir tebessüm îtiyâdıyla enzâra doğru tatlı bir meyl ile kalkıktır. Dişler beyaz mâvimsi olup düzgün ve muntazamdır. Birçok müteverrimlerin diş etleri kırmızı bir kenârla muhât olup dişleri tamâmıyla takip eyler. Gençlerde bu alâim hastalığın pek mebde'inde hâsıl olur. Bu eser [24] bazı meşâhîr-i etibbânın tedkîkâtına nazaran ârâz-1 sâireden iki üç sene evvel kendini gösterir. Hastalık mündefi‘ olmakla başlayınca bu koyuca renkte olan kenâr solgun bir hâle gelir. Aksi hâlde bu kırmızılık ziyadeleşir. Koyu bir renge münkalib olur. Bazı hâmile kadınlarda bu vechile diş kenârı hâsıl olursa da atf-1 ehemmiyyet etmemelidir. Veremlilerin tırnakları da tahavvülâta tâbi'dir. Tırnaklar eğri ve parmak uçları şişkindir.

Sû'-i igtidâ, za'fiyyet vereme istîdâd hâs1l eyler. Husûsiyle kâmet ve endâm ile sıklet-i bedeniyye arasında bir nisbet-i sâbite aramalıdır. Kaviyyü'l bünye ve tâmmü'l 'âfiyye olan bir insân vücûdunun sıkleti, boyun mikdârındaki küsûr-1 a'şariyyeden âzamî yedi veya sekiz kilo kadar noksân olabilir. Bi'l-farz 1,50 metre kâmetinde bulunan bir adamın sıklet-i bedeniyyesi de adedin küsûr-1 a'şâriyyesi olan elli kilo gelmeli, ve hiç olmazsa kırk iki ve kırk üç kilogram olmalıdır. Sıklet-i bedeniyyenin tenâkusu ve husûsiyle bu tenâkusun sür'atle tezâyüdü marazın vehâmetini isbâta kâfidir. Ebeveyninden fazla kâmette bulunan gençler teverrüme müstaiddir. Çocuğu nezâret ve dikkat altında bulundurmalıdır. Verem olanların [25] göğsü de başka şekilde olup arkaya basıkçadır. Göğsün, hastalığın teşhîsinde büyük ehemmiyeti mevcûddur. Ciğerlerin hakkıyla açılıp kabarmamasından ileri gelir ki bunun hayât-1 sıhhiyye üzerinde büyük te'sîr ve nüfûzu vardır. Demek ki bu cihâz; vazîfesini hakkıyla ve tamâmiyle îfâ edemiyor.

\section{[26] Veremin Sûret-i Tedâvîsi}

İbtidâ kat'iyyen emîn olmalıdır ki verem yalnız akciğerlerde karâr kılmayıp bünyeye, tabîata göre tebeddül eder. Binâenaleyh sûret-i tedâvîsi de dâimâ başka başkadır. Bunu ancak bir tabip tâyin ve takdîr edebilir. Cem'iyyet-i beşeriyyenin âdeta hâmî ve nigeh-bân-1 sihhîsi olan doktorlar hastalı̆̆1 teşhîs eder etmez sûret-i tedâvîsini etrâfiyla söyler, anlatır. Yalnız tafsîlât-1 tedâvîkârânesine 
tamâmiyle riâyet ve himmet lâzımdır. Çünki verem yalnız reçete ile kâbil-i tedâvî olmayıp birçok vesâyâ-yı sıhhiyyeye de arz-1 ihtiyâc eyler. Evvelâ teslîm-i hayât edilen doktora tamâmiyle emniyyet ve îtimâd şarttır. Hattâ kalben hazâkatine îtimâdınız ber-kemâl olan bir tabîbi intihâb, hastalığınızın şifâsı husûsunda büyük mikyâsta medhaldârdır.

[27] Emrâz-1 zühreviyyeden bel soğukluğu ve frenginin sûret-i tedâvîsi hakkında Mehmed Sedâd Bey tarafina yazılan bir kitapta beyânât-1 âtiyye muharrerdir: "Bundan on sene mukaddem üçüncü derece verem ile ma'lûl olan bir adamın "pott" denilen illete mübtelâ olmasından dolay1 sırtında ameliyye-i cerrâhiyye icrâ olunmuş ve bununla da kanâat edilmeyerek ciğerlerden eser kalmamıș olan bu bî-çâreye operatörler tarafindan korse giydirilmiș ve bu korse de zavallının ihtiyâcda olan âilesine yirmi liraya mübâyaa ettirilmiștir. Hastanın hâli fenalaşması üzerine tabâbeti hâzıra-i Osmâniyyemizin pîri olan Feyzi Paşa celb olunarak yirmi liralık kıymetindeki işbu korse hastadan çıkarılıp attırılmış ve Paşa-yı müşârün-ileyh kendine mahsûs bir tavır ile: "Ölüme mahkûm üçüncü derecede müteverrim bir bî-çâreye korse giydirmek cinâyettir. Zavallıyı râhat bırakın da üç günlük ömrünü ikmâl etsin!” demiş ve fi'l-hakîka üçüncü günü hasta da vefât etmiştir. Acabâ operatör moda meraklısı bir zât mı imiş ki ölüme mahkûm olan hastasını beli doğru mezâra koyduracağım diye korse iksâsına mecbûr kılmış!”. Tafsîlât-1 ma 'rûzaya göre hastanın sûret ve sür'at-i tedâvîsi tabîbin intihâbındaki isâbetle son derecede alâkadârdır. Ba'dehu bu doktorun vesâyâsına hakkıyla riâyet lâzımdır.

[28] Bugün Avrupa'nın her tarafinda ayrıca veremlilere mahsûs hastahâneler te'sîs edilmiştir. Fenn-i ahîre göre tedâvî edilen birçok müteverrimlerin işfâsı pek çok muvaffakiyyetlerle neticelenmektedir. Bunun için izdihâmlı yerlerden tevakkî etmeli ve kaçmalıdır. Hattâ bunun için tedâvî, vâkî ve şâfî olmak üzere iki kısma tefrîk ediliyor ki tevakkînin tedâvî üzerindeki dahl-i te'sîrini gösterebilir. Şehirlerden kaçmalı, milyonlarca muzır mikropların menbai olan bu galebelikten uzaklaşarak kırlardaki sâfiyyet-i hevâiyyenin bâd-1 füsûnkârına terk-i enfâs etmeli ve semâdan dökülen güneşin şâbâş-1 şu'â'âtı altında mümârese-i bedeniyyede bulunarak bir hayât-1 tabîiyye geçirmelidir. Şehrin dağdağası dimâga te'sîr-yâb olduğu gibi ifsâd-1 hevâdan vücûd müteessir olur.

Hava, müteverrimler için hayâttır. İzdihâmlı mahallerdeki hava sem-dârdır. Buralarda hastanın en ziyâde muhtaç ve müftekir bulunduğu müvellidü’l-humûza azdır. Bâ-husûs ki si ‘a-i teneffüsiyyesi daralmış olan müteverrimler son derecede müvellidü’l-humûzaya muhtaçtır. Zâten teneffüs edilen havada yüzde 21 müvellidü'l-humûza mevcûddur. Hastalığa galebe için buna 20 mikdârında daha ilâve edilmelidir ki telâfi-i mâfât mümkün olabilsin. Galebelik yerlerdeki hava müstâmel olduğundan müvellidü'l-humûza yerine [29] hâmı-1 karbon teneffüs ediliyor ki hadd-i zâtında boğaz hayâta hâdim değildir.

Cereyân-1 hevâdan sakınmalı, tozlu yerlerden tebâ'id etmelidir. İzdivâc bahsinde de esbâb-1 tevakkî mevcûddur. Mehmed Tâhir Beğ'in Vesâyâ-yı İzdivâc nâm eserinde şu sûretle idâre-i lisân edilmiştir: "En mühim bir şey varsa zevce olacak kız ile zevc olacak delikanlının emrâz-1 mühlikeden masûn olup olmadıklarıdır. Mahzâ bidâyet-i izdivâcda icrâ olunan tahkîkât sırasına bu cihetle tedkîki ihmâl ve müsâmaha edilmek sebebiyledir ki bazı izdivâclar zevc veya zevce veyâhûd her ikisi için de mûcib-i saâdet olmak şöyle dursun aynı felâket olup kalır. Meselâ; zevc yâhûd zevcede maâzallahi Teâlâ sillü'r-rie (verem) istîdâdı bulunur. ${ }^{1}$ Yâhûd bu maraz-ı mühlik tarafindan birinde irsen mevcûd olursa izdivâc hem onun mübtelâsını pek çabuk ifnâ eder. Hem de hayâtta kalan refîk yâhûd refîkayı mâ-dâme'l-hayât dağdâr eyler. İşte böyle bir izdivâc tarafeyn için zarar-1 mahzdır. Almanya'da kable'l izdivâc zevc ile zevcenin yekdiğeri hakkında [30] icrâ eyledikleri tahkîkâtın en mühimmini muâyene-i tıbbiyye teşkîl eylemektedir. Binâenaleyh bu husûsa da îtinâ-kâr olmalıdır.

\footnotetext{
${ }^{1}$ Verem başka dâ'ü's-sill (Phtisie) başkadır. Bunların arasındaki fark, cildin hafifçe kat'`1 ile bütün bir uzvun kesilip atılmasındaki fark gibidir.
} 
Veremin tedâvî-i şâfîsi, ancak marazın ibtidâsında mümkündür. Bu da birkaç türlü olup mutlakâ bir tabip eline muhtaçtır. Böyle bir doktorun nezâret-i mütemâdiyyesi altında edilen tedâvî ale'l-ekser muvaffakiyetle hitâm bulur. Eğer maraz ilerlemişse edviye de lâzımdır. Taâmı ve muntazam cevelânları müteâkib şezlongda istirâhat-nişîn olarak sâkinâne dem-güzâr olmalıdır.

Mesâîde ifrât kat'iyyen muzırdır. Bir sâat çalışırlarsa bir sâat de gezmeli, rûhu, dimâg1, vücûdu müsterîh bırakmalıdır. Gezmek bir sâatten fazla devâm etmemelidir. Cereyân-1 hevâdan sakınmalı, hançere, boyun güzelce muhâfaza olunmalıdır. Vücûd terlerse hemân çamaşır değiştirmelidir. Roman gibi âsâbı tehyîc ve halecâna düşürecek mütâlaalardan müctenib durunmalıdır. Araba ile gezilecek olursa yatmalı ve arka mutlakâ bir yere dayanmalıdır. Araba ile gezmek mutlakâ doktorun tensîb ve tavsiyesine göredir. Yaya olarak gezmek için terlememeğe, üşümemeğe son derece gayret etmelidir. Uzun gezintilerden sarf-1 nazar edip dâimâ düz, tesviye edilmiş ağaçlık ve güneşli mahallerde dolaşmalıdır. [31] Taâmı müteâkib lâ-akal bir sâat kadar istirâhat-güzîn olmak lâzımdır. Fakat bu istirâhat oturmakla değil, yatmalıdır.

Bu hastalığın tedâvîsinde huzûr-1 kalb yegâne devâdır. Hadd-i zâtında ekdâr kadar cümle-i asabiyyeyi tahrîb ve cihâz-1 hazmiyyenin vezâifini sekte-dâr eden bir mâni` olamaz. İstirâhatten maksad-1 aslî işte bu kalbi mânevî düşüncelerden, fikri âzâde-ser bırakmaktır. Esâsen verem vücûdu kemirici bir hastalıktır. Bununla mübâreze etmek için sarfiyyâtı azaltmak, me'hûzâtı ve vâridâtı teksîr etmek şarttır. Bunun için zıyâ' ${ }^{6}-1$ kuvvette iktisâd etmelidir.

Vücûd-1 beşeri ihâta eden cildin bir vazîfesi de ciğerler gibi teneffüs eylemesidir. Bunun mesâmâtından da müvellidü'l-humûza girer. Ve bundan başka hayât-1 beşere hâdim olan harâreti de bütün bedene müsâvâten taksîm ve tevzî‘ eyler. Cildin diğer vazîfesi de vardır ki bu da bedende müterâkim mevâdd-1 muzırrayı ter vâsıtasıyla hârice def" eylemektir.

Veremlilerin fazla mikdârda müvellidü'l-humûzaya ihtiyâcları derkâr ve vücûddaki zehirli mikropları def'e olan zarûretleri âşikâr olduğundan derinin hüsn-i sûretle vazîfesini îfâ etmesi hayât1 sıhhiyye üzerinde pek mühim bir rol oynar. Binâenaleyh veremlilerin banyo [32] etmeleri lâzımdır. Fakat bunun sıcak ve soğuk su ile icrâsı için mutlakâ doktorun bi'l-muâyene tavsiyesine lüzûm vardır. Hastalara suyun fâidesi lâ-şekk ve şübhedir. Ancak bunun istîmâli için tedâbîr-i ihtiyâtiyyeyi unutmamalıdır. Zîrâ ufak bir ihtiyâtsızlık aksü'l-amel tevlîd eyler. Soğuk su, hâl-i batâet ve atâlette kalmış olan vezâif-i hayâtiyyeyi tenbîh ve âsâbı tahrîk eyler ve bunların faâliyeti vücûdda hüsn-i te'sîr uyandırır.

Elektriğin vücûda nef'i nâ-kâbil-i reddir. Husûsiyle elektrikle veremin tedâvîsindeki semereyi, Avrupa'da müesses sanatoryumlar dâimâ iktitâf etmektedir. Fakat bunu idâre edecek eller, dimâglar mâhir ve sâhib-i vukûf olmalıdır. Elektrik, evvelâ evcâ'-i maraziyyeyi tahfîf ve teskîn ve igtidâ-yı bedeni te'mîn ve ihtikânı ta'kîm kılar. Esâsen mâder-zâd kuvvetsizlikler için bile elektrik tavsiye edilmekte olduğundan müteverrimlere olan fâidesini uzun uzadıya zikre değmez. Çünki müteverrimlerin kuvvete ihtiyâcı emrâz-1 sâire mübtelâlarından mukaddemdir.

Öksürük mes'elesi müteverrimlerin en ziyâde suûbet çektikleri bir arazdır. Öksürük hançerede ve akciğerlerde terâküm etmiş olan mevâdd-1 ecnebiyye ve muzırrayı def" etmek içindir ki bunların vücûdda kalması hastanın sühûlet-i teneffüsüne usret verir. Ancak, [33] balgam getirmeyen öksürüklere mümkün mertebe imsâk etmeğe çalışmalıdır, tahammül eylemelidir. Zîrâ ancak bu sûretle gaseyân ve kan tükürmelerin bir dereceye kadar önü alınabilir. Her ne kadar ibtidâları bu kuru öksürüklere tahammül güç olursa da sabr u mukâvemet eylemelidir. Balgam geldiği vakit bunu îtinâ ile ya bir tükürük hokkasına veya mendile atmalıdır. Ve ba'dehu mendili gâyet sıcak su ile kaynatmaksızın kat'iyyen kullanmamalıdır. Çünki def' edilen muzır mikroplar, mendilde kuruyan balgamlardan tekrâr sirâyet imkânını bulabilirler. Balgam tükürdükten sonra ağzı temiz bir su ile yıkayıp çalkalamak fâideden hâlî değildir. 
Veremlilerde si‘a-i sadriyye gayr-i kâfî bulunduğundan bunu mümârese-i bedeniyye ve elektrikle izâleye çalışmalıdır. Vücûdu yormaksızın si'a-i sadriyyeyi tevsî‘e çalışarak ciğgerleri mebzûl hava ile doldurmak fâide-bahş olduğu gibi hastalığın işfâsına dahl ve te'sîri vardır. Eğer akciğer hücrelerinden bazıları her ne sebeple olursa olsun hareketten mahrûm ve mehcûr kalırsa oradaki koch basillerinin takarrür ve tekessürünü ${ }^{2}$ teshîl eyler. Mümârese-i teneffüsiyye ise bu muzır, zehirli mikropların oralarda tevazzu'ına mâni' olur veya tenemmüv ve tekessürünü az ve çok te'hîr ve ta'rîk eder.

Mümârese-i teneffüsiyyenin envâ‘ 1 vardır. Maamâfih ciğerin tâ kâ'idesinden [34] zerresine kadar bütün aksâmını hava ile imlâya muvaffakiyyet hâsıl eden her mümârese yormamak şartıyla nâfi'dir. Burunda, boğazda birçok habbecikler vardır ki bunlar verem mikroplarını muhâfazaya müsâiddirler. Bademciklerde muhâtaralıdır. Burası da basillere bir dârü'l-amân olabilir. Bunlar hep teneffüsle alâkadâr olduğu için tahârete, izâlelerine lüzûm-1 kat'î tabiîdir.

İklîm intihâbı mes'elesi gerek hastaları ve gerek bazı etibbâyı düşündürmektedir. Hâlbuki iklîmin hastalık üzerindeki te'sîrâtı hurâfât kabîlindendir. Sâf hava nerede ise, hasta da oradan istifâde eder. Ne sıcak verem hâsıl eder ve ne de soğuk vereme mâni‘ olur. Hâlbuki soğuğun sicağa nisbeten rüchânı vardır bile. Ancak soğuktan tevakkî şartıyla. Hastalar için iklîmin bir kıymeti olmayıp doktorların hazâkati lâzımdır. Takayyüdât-1 tıbbiyye tedâvî-i şâfî için mübremdir. Binâenaleyh sâbit bir harâretle, gayr-i mütehavvil bir rutûbet veremlilerin tedâvîsi için aranılacak bir keyfiyyettir.

Verem ârâzını tahfîf etmek için en müessir ve sehîl çâre tedâvî-i hevâiyyedir. Temiz, sâf kır havası teneffüsünün kansızlığa, emrâz-1 asabiyyeye, kan bozukluğuna karşı olan te'sîrât-1 hasenesi muhakkaktır. [35] Fakat bu temiz hava teneffüsü yalnız gündüzlere mahsûs ve münhasır kalmayıp gecelere de teşmîl edilmelidir. Soğuk ve sâf hava ensicedeki mevâdd-ı mesmûmeyi, muhtevî olduğu müvellidü'1 humûza vâsıtasıyla çabucak def" eder. Âsâbı kuvvetlendirir. Ciğerlerin bu hevâ-yı sâf ile dolması muzır mikropların barınmasını tas'îb eyler. Binâenaleyh verem ârâzını gösteren bir hasta alelacele şehirlerden uzaklaştırılmalı, sâf hava teneffüsüne îtinâ olunmalıdır.

Mesken intihâbı mes'elesi de veremliler için ehem ve şâyân-1 kayd ve tezkârdır. Bu bâbda en iyi mesken binânın şimâl-i şarkîden cenûb-1 garbîye müteveccih olmasıdır. Bu sûretle hava ve güneş binâ dâhiline lüzûmu mikdârda girebilir ve hastanın en ziyâde muhtâc olduğu teneffüsü teshîl eyler. Odalar ne kadar geniş ve havadâr, pencereler ne kadar büyük ve havanın tebeddül ve cereyânına müsâid ise o nisbette şâyân-1 rüchândır. Ziyâ-yı şems dâimâ hastanın bulunduğu odaları 1lık harâreti, menba'-i kuvvet ve ciyâdet olan şâbâş-1 ziyâiyyesiyle yıkamalıdır. Pencerelere muallak perdeler gâyet ince olmalıdır ki güneşin sühûlet-i duhûl ve nüfûzuna mâni‘ olamasın. Zîrâ güneş hastanın vücûdundaki tufeylât-1 sagîreye en müessir bir zehirdir.

[36] İksâ edilen elbise hafifliği nisbetinde bedeninizi soğuktan koruyacak ve vücûdunuzun harâret-i tabîiyyesini izâ'a etmeyecek derecede olmalıdır. Kadınlar için korse istîmâli hadd-i zâtında muzır olduğundan hastalık esnâsında bundan kat'iyyen tevakkî ve ihtirâz eylemelidir. Bu hâlde veremli için en nâfiz ve müessir tedâvî; güneş, istirâhat, banyo ve muâlece-i husûsiyye ile mümkündür. Taab, şifânın düşmanıdır.

\section{[37] Müteverrimlerin Sûret-i Tagaddîsi}

Kitâbımızın müsemmâsı olan "verem" maraz-1 müzmin ve mühlikenin ibtidâsı teverrümdür ki vesâit-i tıbbiyye ile dâimâ şifâ-pezîr olmakta ve devre-i intihâsı "sillü'r ri'e" olup gayr-i kâbil-i şifâ bulunmaktadır. Maamâfih hastalığın birinci devresindeki sûret-i tedâvî devre-i ahîresindeki tedâvîye nisbetle gâyet sehîl olup vesâyâ-y1 ma'rûzaya ittibâ'-1 hareket eyleyenlerin hemân kâffesi hayâtlarını kurtarmış olurlar. Bu halâs kendi yed-i iktidâr ve ihtimâmlarındadır. Devre-i ahîrede

\footnotetext{
${ }^{2}$ Metinde "teksîr” yazmaktadır. Ancak, anlam bakımından uymadığı için “tekessür” olarak kaydedildi.
} 
bulunan hastalara gelince bunların da \% 25'i sanatoryumlarda halâs-yâb oluyorlar. Ancak bu halâs tabiplerin fedâkârlığıyla berâber hastaya birinci sûretteki kadar ucuza mâl olmuyor. Bu iki devre arasındaki zamân hüsn-i istîmâl edilirse ve tedâvîye ihtimâm ve himmet olunursa mutlak şifâ-pezîr olur.

[38] Binâenaleyh bir veremlinin tagaddîsi mes'elesi bu husûsta ehemmiyyetle telakkîye sezâdır. Hazmı müteassir olan et 'ime hem hastanın cihâz-ı hazmiyyesindeki bozukluğu teşdîd eyler ve hem de hastanın aksâ-yı emeli olan emr-i tedâvîsinde de mâkûs netîceler tevlîd eder. Gıdâ, hayât1 beşerin bekâsıyla alâkadârdır. Bâ-husûs hastalık esnâsında bunun hüsn-i te'mînindeki ihtiyâc tezâuf eyler. Etibbânın hulâsa-i vesâyâsı ve veremlilerin muvaffakiyyet-i şaffiyyesi için vird-i zebân eyledikleri ihtârât-1 fenniyyesi hep tagaddî husûsuna ma'tûftur. Bir hasta taâmı hüsn-i intihâb eyler ve hazımca da sühûlet hissederse mutlakâ şifâ-yâb olur.

Vücûd-1 beşerin müteşekkil olduğu anâsır, mâdenî ve uzvî olmak üzere ikiye münkasım olup bunlar da manganez, hadîd, klor, sodyum, potasyum, kalsiyum, flor, fosfor, müvellidü'l-mâ', müvellidü'l-humûza, fahm, kükürtten ibârettir. Bunlar müteferrik bir sûrette bulunmayıp mürekkeb bir hâlde cisimler hâsıl eylerler. Bu mürekkebât vücûdumuza hep tagaddî sûretiyle idhâl olunur. Bu hâlde veremin vücûdda hâsıl eylediği zıyâ‘ ${ }^{`}$ telâfî eyleyecek gıdâları yegân yegân zikr etmek maksadı az çok te'mîn eyler.

[39] Maamâfîh yalnız tagaddîdeki isâbet sûret-i matlûbede muvaffakiyyeti intâc eylemez. Bu gidâların hazmı da düşünülmelidir. Sühûlet-i hazm tedâvî için tagaddî kadar ehemmiyyetlidir. Ancak hazım, gıdâ ve hangi şeylerin tagaddîye elverişli olduğuna mükemmel bir mîyârdır.

Evvelâ, ekmekten başlayalım. Ekmek gâyet nefîs bir gidâdır. Ancak bunun güzel pişirilmiş olması lâzımdır. Renk cihetiyle ne pek esmer ve ne de gâyet beyâz bulunması fâide-bahş olamaz. Bunun vasatını bulmak evlâdır. Çünki gâyet beyâz ekmek yalnız nişastadan ibârettir.

Hubûbâttan buğday, pirinç ve mısır gâyet nâfi‘ gıdâdır. Memleketimizde pirinç mebzûlen müstâmeldir. Esâsen hacmine göre en ziyâde kuvve-i gidâiyyeyi hâvî olan pirincin \% 77'si nişasta, \% 0,9'u yağ, \% 7'si de zülâliyyâttır. Pirinçte fahm, sâir gıdâlara nisbetle daha çoktur. Ancak pirincin gâyet nefîs pilav sûretiyle ekli müreccahtır. Mi`deyi yorgun düşürmemesi ancak böylece tabhındadır.

Lahm her ne kadar veremliler için en mükemmel bir gıdâ ise de fî yevminâ hâzâ bunun bütün hastalıklar için vâsıta-i sirâyet olduğu fikri gâlip gelmektedir. Ancak mükemmel sûrette pişirildikten sonra bu şüphe de ber-taraf olur. [40] Avâm-1 nâs arasında her sabâh bir parça çiğ et yutulma tavsiyesi zebân-zed ise de bu gibi âmiyâne tavsiyelere kulak asılmamalıdır. Hayvânâtın hastalıklardan mücerred kalması mümkün olamadığından muzır mikropların bu sûretle sirâyeti de tabiîdir. Ette mevâdd-1 azotiyyenin mebzûl bulunması kuvve-i gıdâiyyesini teksîr eyliyor. Hazmı da kolaydır.

Şahm ve nişastalı mâddeler vücûdda harâret husûle getirir. Vücûd, lüzûmu derecesinde tagaddî edemezse tahte'l-cild bulunan yağlara mürâcaat ederek kuvve-i hayâtiyyesini idâme eyler. Zâten bu yağlar harâret-i bedeniyyenin muhâfazasına da hâdimdir. Veremlilerde ise bu yağlar, za'fiyyetleri hasebiyle azalmış bulunduğundan doktorların nişastalı mâddeleri ve yağ tavsiyeleri doğru ve musîbdir.

Yumurta da gıdâların en mükemmelidir. Bunda azottan başka vücûda en nâfi‘ ve fosforlu bir mâdde de mevcûddur. Çiğ yumurtanın vücûda fâidesi rafadan yumurta kadar değildir. Fi'l-hakîka mukaddemâ çiğ yumurta tavsiye edilmekte idiyse de el-yevm Avrupa etibbâsınca bundaki hâssa-i gıdâiyyenin çiğ hâlinde iken derece-i muntazarada olmadığı bi't-tecrübe sâbit olmuştur. Binâenaleyh yumurta rafadan olarak ekl edilmelidir. Süt de sehlü'l-hazm bir gıdâ ise de et ve yumurtaya nisbetle daha mugaddîdir. Çünki azotun [41] mikdârı diğerlerine nazaran aşağıdır. Sütün tavsiyesi, hastanın şahsına göre değişiri. Bazılarına ishâl verir. 
Bugün bazı etibbâca yoğurt, süte tercîh edilmektedir. Bu mes'ele henüz sûret-i kat'iyyede sâbit olmadığından her tabip kendi tecrübesine göre usûl takip etmektedir. Maamâfîh bütün bu gıdâların sû'-i istîmâli hazmı bozar. Hazım ise, hayât-1 umûmiyye-i maraziyye üzerinde mühim rol îfâsına me'mûrdur.

Havanın gıdâ üzerine olan te'sîrini tedâvî bahsinde zikr etmiştik. İnsân günde yirmi bin defa nefes alarak ciğerlerine takrîben on bin litre kadar hava alır. Ancak bu havanın sâfiyyeti alınan gıdânın vücûda nafi‘ olmasına ve cihâz-1 hazmiyyenin intizâm-1 harekâtına pek çok hidmet eder.

Sebzeler tâze ve kuru olmak üzere ikiye münkasımdır: Tâze sebzeler, o kadar mugaddî olmayıp mideyi fazlaca doldurmak ve em 'âyı beyhûde çalıştırmaktadır. Bunun için müteverrimlere tâze sebze tavsiyesinde imsâk etmelidir. Kuru sebzeye gelince, nohut, mercimek, fasulye gibi azotu çok olanlar şâyân-1 tavsiye ve bunların mevâdd-1 gıdâiyyesi diğerlerine nisbetle çok fazladır.

Veremliler için müskirât istîmâli etibbâca bazı kuyûd [42] dâhilinde kabûl ve tavsiye edilmekte ise de meşrûbât meyânında iyi ve sâf olmak şartıyla sudan başkasına cevâz verilmemelidir. Küûlü gâyet az olarak yemeklerde yarım bardak kadar kırmızı şarap içmek zarar vermez. Yoksa muayyen zamânlarda meşrûbât-1 küûliyye veremliler için bilhâssa tavsiyeye değmez. Bira hulâsası küûlü az miktarda olan biranın içilmesi hazım için müfîddir. Maamâfîh meşrûbât mes'elesi tabîbin re’y ve tecâribine göre değişir. Hitâm.

\section{Sözlük}

A

aded-i darabât: (Kalp için) Çarpma sayısı.

aded-i musâbîn: Hastalığa yakalanmış olanların sayısı.

adem: $A r$. Yokluk.

adem-i faâliyyet: Hareketsizlik.

adem-i kifâye / adem-i kifâyet: Yetmezlik.

adem-i tevâzün: Dengesizlik.

âdet-i şehriyye: Aylık âdet (döngüsü), aybaşı.

ahvâl-i maraziyye: Hastalık halleri.

ahvâl-i tabîiyye: Tabii haller.

ahvâl-i zâhiriyye: Görünüşteki durumlar, haller.

âkil ve bâliğ olmak: Bülûğa ermek, cinsel olgunluk çağına girmek.

aksâ-yı emel: Büyük emel, ülkü.

aksü'l-amel: Tepki, reaksiyon.

alâim: $A r$. Alametler, belirtiler.

alâim-i gayr-i tabîiyye: Tabii olmayan belirtiler. alâmet-i mümeyyize: Ayıran, temyiz eden belirtiler.

alâmet-i sâbite-i teverrüm: Veremin açı belirtileri.

alâmet-i teverrüm: Verem belirtileri.

ale'l-ekser: $A r$. Çoğunlukla.

ameliyye: $A r$. Pratik.

ameliyye-i cerrâhiyye: Cerrahi işlemler.

âmil: Ar. Sebep.

anâsır: $A r$. Unsurlar.

araz: Ar. (Hastalık için) Belirti, bulgu, semptom.

ârâz: Ar. Hastalık belirtileri, bulgular, semptomlar.

ârâz-ı sâire: Diğer belirtiler, semptomlar.

ârız olmak: (Hastalık için) Görülmeye başlamak, musallat olmak.

arz-ı iftikâr etmek: Bir şeye boyun eğmeğe mecbur olmak.

arz-ı ihtiyâc eylemek: İhtiyacını belirtmek, ortaya koymak. 
âsâb: $A r$. Sinirler.

âsâr: Ar. Belirtiler, alâmetler.

âsâr-ı teverrüm: Verem belirtileri.

asr-ı ahîr: Son asır.

âşikâr: Far. Açık.

atf-ı ehemmiyyet etmemek: Dikkate almamak, önem vermemek.

atşân: $A r$. Susuz, susamış.

ayan: Ar. Belli, açık.

avâm-ı nâs: Halk.

avdet: $A r$. Dönme, dönüş.

âzâde-ser: Far. Başı dinç, rahat.

âzamî: $A r$. En çok, en fazla.

âzâ-yı beden: Vücudun organları.

âzâ-yı bedeniyye-i hâriciyye: Dış organlar.

âzâ-yı hâriciyye-i bedeniyye: Vücudun dış organlar1.

âzâ-yı hazmiyye: Sindirim organları.

\section{B}

bâd-ı füsûnkâr: Büyüleyici hava.

bahşetmek: Far. $+T$. Vermek, bağışlamak, ihsan etmek.

bâ-husûs: Far.+Ar. Özellikle, bilhassa.

bâis-i endîşe ve takayyüd olmak: Endişe ve kayg1 sebebi olmak.

basil: $F r$. $<$ Lat. Çomak şeklindeki ince uzun bakterilere verilen isim.

batî: Ar. Yavaş, ağır hareketli.

beden-i dâhilî: İç beden.

beden-i insânî: İnsan vücudu.

bedîdâr: Far. Açık, meydanda.

bekâ: $A r$. Devam, bakilik.

ber-hayât: Far. $+A r$. Hayatta, sağ, diri.

ber-kemâl: Far.+Ar. Mükemmel. beyânât-ı âtiyye: Aşağıdaki açıklamalar.

bi'l-farz: $A r$. Farzedelim ki, sözgelişi.

bi'l-muâyene: $A r$. Muayene ederek.

bi'n-netîce: $A r$. Netice olarak, sonuçta.

bi’t-tabî'‘: Ar. Doğal olarak.

bi't-tecrübe: $A r$. Tecrübe ile, tecrübe yoluyla.

bidâyet: Ar. Başlama, başlangıç.

bidâyet-i izdivâc: $A r$. Evlilikten önce.

bilâ-istifâde: $A r$. İstifade etmeksizin.

C

cebhe: $A r$. Alın.

celb: Ar. Çağırma.

cem'iyyet-i beşeriyye: İnsan topluluğu.

cenîn: Ar. Anne karnındaki çocuk, döl.

cenûb-ı garbî: Güneybatı.

cereyân: Ar. Akma, akım.

cereyân-ı hevâ: Hava akımı.

cevelân: Ar. Dolaşma, gezinme.

cezâ-yı nakdî: Para cezası.

cidâl-gâh: Arr.+Far. Savaş meydanı.

cihâz: Ar. Aygit, organ.

cihâz-ı dâhiliyye: İç organ.

cihâz-ı hazmiyye: Sindirim organı.

cihâz-ı teneffüsiyye: Nefes alma organı.

cümle-i asabiyye: Sinir sistemi.

D

dâ'-i küûl: Alkol düşkünlüğü, alkolizm.

dağdağa: Ar. Gürültü, patırtı.

dâhilî: $A r$. İç ile ilgili.

dâhil-i beden: Bedenin iç kısmı.

dahl-i te'sîr: Tesir etme.

dârü'l-amân: Korunulacak, sığınılacak yer. 
delâlet: $A r$. Belirti, işaret, alâmet.

dem-güzâr olmak: Vakit geçirmek, yaşamak. dendân-ı mühlik: (Verem için) Helak edici, öldürücü dişler.

derece-i muntazara: İstenilen derece.

derkâr: Far. Aşikar, bilinen, belli.

devâ: Ar. İlaç.

deverân-ı dem: Kan dolaşımı.

devre-i ahîre: Son evre, son safha.

devre-i intihâ: Son evre, son safha.

dimâg: $A r$. Beyin.

dûçâr: Far. Tutulmuş, uğramış, yakalanmış.

dûr: Far. Uzak.

düşvâr: Far. Güç, zor.

E

edviye: $A r$. Devalar, ilaçlar.

ehemm: $A r$. En önemli.

ekdâr: $A r$. Kederler.

ekl: $A r$. Yeme.

el-yevm: Ar. Bugün, bugünkü durumda.

em‘â: Ar. Bağırsaklar.

emniyyet: $A r$. İnanma, güvenme.

emrâz: $A r$. Hastalıklar.

emrâz-ı asabiyye: Sinirsel hastalıklar.

emrâz-ı kadîme: Eski hastalıklar.

emrâz-ı ma'dûde: Belirli hastalıklar.

emrâz-ı muhtelife: Çeşitli hastalıklar.

emrâz-ı mühlike: Öldürücü hastalıklar.

emrâz-ı sâire: Diğer hastalıklar.

emrâz-ı sâriye: Bulaşıcı hastalıklar.

emrâz-ı vahîme: Tedavisi mümkün olmayan, tehlikeli, ağır hastalıklar.

emrâz-ı zühreviyye: Zührevi hastalıklar. emr-i tedâvî: Tedavi işi, tedavi konusu.

endâm: Far. Vücut, beden.

ensâc: $A r$. Dokular.

ensâc-ı muhtelife: Çeşitli dokular.

ensice: $A r$. Dokular.

ensice-i vechiyye: Yüzdeki dokular.

ensice-i vücûdiyye: Bedensel dokular.

enzâr: Ar. Bakışlar, nazarlar.

esâtize-i etibbâ: Tıp üstatları, tıp ustaları.

esbâb-ı intişâr: Yayılma sebepleri.

esbâb-ı tevakkî: Korunma sebepleri.

esîr-i memât eylemek: Ölümün esiri yapmak.

etfâl: $A r$. Çocuklar.

etibbâ: Ar. Tabipler, tıp doktorları.

etibbâ-yı kadîme: Evvelki tabipler, eski tabipler.

et'ime: $A r$. Yemekler, aşlar.

evcâ'-i maraziyye: Hastalıkla ilgili ağrılar.

evlâ: Ar. Daha iyi.

evsâf-ı mahsûse: Özel sebepler, kendine has özellikler.

ezcümle: $A r$. Bunların içinden, örnek olarak.

ezmine-i kadîme: Eski zamanlar.

F

faâl: $A r$. Etkin, aktif.

faâliyet-i hayâtiyye: Hayati faaliyetler.

fahm: Ar. Karbon.

fâide-bahş: Ar. +Far. Fayda sağlayan.

fakrü'd-dem: Kansızlık.

fenn-i ahîr: En son bilgiler.

fî yevminâ hâzâ: Bugünkü günde.

G

gâib eylemek: Kaybetmek. 
galebe: $A r$. Yenme, üstesinden gelme.

galebelik: $A r .+T$. Kalabalık.

gaseyân: Ar. Kusma, kay etme.

gayr-ı me'mûl: Umulmadık, beklenmedik.

gayr-ı müessir: Tesir etmeyen, etkisiz.

gayr-i kâbil-i şifâ: Şifa bulması mümkün olmayan.

gayr-i kâfî: Yetersiz.

gayr-i mütehavvil: Değişmeyen.

germî: Far. Hararet, sıcaklık.

gışâ: Ar. Zar, örtü, koruyucu tabaka.

gışâ-yı muhâtî: Vücudun boşluğunu kaplayan iç deri.

\section{H}

habbecik: $A r .+T$. Küçük tane; gudde, bez; kabarcik.

hadd-i zâtında: Esasen yaradılışta, aslında.

hadîd: $A r$. Demir.

hâdim: Ar. Hizmet eden, yarayan.

hâiz: $A r$. Malik, sahip.

hakâyık-ı mâkûse: Acı gerçekler.

hakâyık-1 müsebbete: Doğrulanmış gerçekler.

halâs: $A r$. Kurtulma, kurtuluş.

halâs-yâb: Ar.+Far. Kurtulan.

hâlât: $A r$. Haller.

halecân: $A r$. Çarpıntı.

halel: $A r$. Eksiklik, bozukluk.

hâlet-i kuvâ: Gücü kuvveti yerinde olma hali.

hâl-i tabîiyye: Doğal hal.

hâmız-ı karbon: Karbonik asit.

hâmî: Ar. Koruyan, koruyucu.

harâret-i bedeniyye: Vücut 1sısı.

harâret-i tabîiyye: Vücudun doğal sıcaklığı. harâret-i tabîiyye-i beşer: İnsan vücudunun doğal isisi.

hâssa: Ar. Nitelik, güç, kuvvet.

hâssa-i gıdâiyye: Besleyici nitelik.

havf: $A r$. Korku, korkma.

hâvî: Ar. İhtiva eden, içine alan.

hayât-ı beşer: İnsan hayatı.

hayât-ı beşeriyye: İnsana ait hayat.

hayât-ı sıhhiyye: Sağlıklı hayat.

hayât-ı tabîiyye: Doğal hayat.

hayât-ı umûmiyye-i maraziyye: Hastalığın genel ömrü.

hazâkat: $A r$. (Hekimler için) Üstatlık, ustalık.

hazım: $A r$. Sindirim.

hevâ-yı sâf: Temiz hava.

hevl-nâk: Korkunç, korkulu.

hey'et-i ictimâiyye-i beşeriyye: İnsan topluluğu.

hıfz-ı sıhhat: Sağlı̆̆ koruma.

hıfz-ı sıhhat-i agdiye: Sağlığı koruyan gidalar.

hilkat-i vücûdiyye: Vücudun yaradılışı, yaradılıştan olan durum.

himmet: Ar. Gayret, çalışma, çabalama.

hitâm bulmak: Sona ermek.

hubeyb-i derenî: Verem habbeciği, tüberkül.

hulâsa-i vesâyâ: (Hekimlerin) uyulmasını istedikleri hususlar, davranışlar.

hummâ: Ar. Ateşli hastalık, sıtma.

hurâfât: $A r$. Aslı esası olmayan sözler, rivayetler.

hurde-bîn: Far. Büyüteç, mikroskop.

huzûr-ı kalb: Kalp huzuru, gönül rahatlığı.

hüsn-i îfâ: İşi iyi yapma.

hüsn-i intihâb: İyi seçim. 
hüsn-i istîmâl: İyi kullanma.

hüsn-i sûret: İyi bir sûret.

hüsn-i te'mîn: Güven sağlama.

hüsn-i te'sîr: İyi etki.

I

Itlâk: Ar. Deme, denilme.

I

ibtidâ: Ar. Başlangıç.

ibtidâr: Ar. Başlama, başlangıç.

icrâ-yı te'sîr: Tesir etme.

icrâ-yı vazife: Görevi yerine getirme.

ictimâî: Ar. Sosyal.

idâme eylemek: Devam ettirmek.

idâre-i lisân etmek: Önünü sonunu düşünerek, durumu idare edecek şekilde dile getirmek.

idhâl: Ar. Alma, dahil etme.

îfâ: $A r$. Yapma, yerine getirme.

îfâ-yı vazîfe: Vazifesini yapma.

ifnâ: $A r$. Yok etme, tüketme.

ifrâgât: Ar. Boşaltımlar, excreta.

ifrât: $A r$. Aşırı gitme, ileri varma.

ifrât-ı mesâî: Fazla mesai.

ifrâz: $A r$. Vücutta kan, cerahat, irin ter gibi ayrılıp çıkan şey, salgı.

ifrâzât: $A r$. Vücutta kan, cerahat, irin ter gibi ayrılıp çıkan şeyler, salgılar.

ifrâzât-ı zehr-nâk: Zehirli salgılar.

ifsâd-ı hevâ: Havanın bozulması.

igtidâ: $A r$. Gıdalanma, yiyip içme.

igtidâ-yı beden: Bedenin beslenmesi.

igtidâ-yı tabîi: Doğal beslenme.

ihâta: Ar. Kuşatma, sarma.

ihtârât-ı fenniyye: Bilimsel uyarılar. ihtikân: Ar. Kan birikmesi, congestion.

ihtirâz: $A r$. Sakınma.

ikmâl: $A r$. Tamamlama, bitirme.

iksâ: $A r$. Giydirme, giydirilme.

iktisâd: Ar. Aşırı gitmeme, davranmama, tutum, tutma.

iktitâf: Ar. Bir çalışmanın neticesinden faydalanma, karşıllı̆ını görme.

i'lâm: Ar. Bildirme, bildirilme.

i'lân: Ar. Meydana çıkarma, açığa vurma, ilan.

ilkâ: Ar. Meydana getirme; verme.

illet: $A r$. Hastalık.

illet-i asabiyye: Sinirsel hastalık, asabî hastal1k.

iltihâb-ı kasabât: Akciğer borularında meydana gelen kızarma ve öksürük.

imlâ: $A r$. Doldurma.

imsâk etmek: Kendini tutmak, el çekerek nefsine hâkim olmak.

inkıtâ': Ar. Bitme, kesilme.

intâc: $A r$. Sonuçlandırma.

intân: $A r$. Mikroptan ileri gelen bulaşıcı hastal1k.

intânî: $A r$. Mikrobik.

intihâb: $A r$. Seçme, ayırma.

intikâl: $A r$. Birinden diğerine geçme.

intizâm: $A r$. Düzenli olma.

intizâm-ı harekât: Düzenli hareketler.

intizâm-ı hayâtiyye: Düzenli hayat.

irsen: Ar. Soyaçekimle ilgili olarak, irs yoluyla.

istîdâdât-ı irsiyye: Genetik yatkınlıklar.

istîdâd-ı habâis: Kötü şeylere meyilli olma.

istîdâd-ı irsiyye: Genetik yatkınlık. 
istîfâ: Ar. Alınma, ödetilme.

istilâ: $A r$. Yayılma.

istîmâl: $A r$. Kullanma.

istinbât-ı illet: Hastalık hükmünün verilmesi.

istirâhat-güzîn: $A r .+F a r$. Dinlenmeyi seçen.

istirâhat-nişîn: $A r .+F a r$. Oturarak dinlenen.

işfâ: $A r$. Şifa bulma, iyileşme.

iştigâl: $A r$. Meşgul olma.

îtimâd: $A r$. Güvenme.

îtinâ-kâr: Ar.+Far. Çok dikkatli, özenli.

îtiyâd: Ar. Alışkanlık.

itlâf: $A r$. Telef etme.

ittibâ'-1 hareket: Davranışa tabi olma, uyma.

izâ'a etmek: Açı̆̆a vurmak.

izâle: $A r$. Giderme, giderilme, yok etme.

izdihâm: $A r$. Kalabalık yığılma.

izdivâc: $A r$. Evlenme.

K

kâbil-i ekûl: Yenilebilir.

kâbil-i tedâvî: Tedavi edilebilir.

kâbil-i tefrîk: Ayırt edilebilir.

kable'l izdivâc: Evlilikten önce.

kâffe: $A r$. Bütün.

kâil olmak: Razı olmak, boyun eğmek.

kâmet: Ar. Boy, boybos.

karâr-kâr: Ar.+Far. Kararlı.

kaviyyü'l bünye: Bünyesi kuvvetli olan.

kay: Ar. Bulant, kusma.

kesb-i batâet: Yavaşlık kazanma, ağır davranma.

kısm-ı âzam: Büyük kısım.

koch basili: (Alman hekimi Robert Koch'un adından) Tüberküloza sebep olan basil. kuvâ-yı mukâveme-i tabîiyye: Doğal dayanma gücü.

kuvve-i gıdâiyye: Beslenme gücü.

kuvve-i hayâtiyye: Hayatî güç.

kuyûd: Ar. Kayıtlar.

küre-i arz: Yeryüzü.

küreyvât-ı beyzâ: Akyuvarlar.

küsûr-ı a'şâriyye: Ondalık kesirler.

küûl: Ar. Alkol, ispirto.

$\mathbf{L}$

lâ-akal: $A r$. En azından.

lahm: $A r$. Et.

lâşe: Far. Leş.

lâ-şekk ve şübhe: $A r$. Şüphesiz.

lenfa: Lat. Beyaz kan, vücutta ince damarların içinde dolaşan, kanın esasını teşkil eden ve eskilerin ahlât-1 erbaa dedikleri bu dört maddeden biri.

lenfavî: (Lenfanın Arapçalaşmış şekli) Lenf nisbeti fazla olan, kansız, zayıf vücut yapısının özelliklerini taşıyan mizaç, lenfavî (mizaç).

lisân-ı avâm: $A r$. Halk dili.

M

maâzallahi Teâlâ: Ar. Allah saklasın, Allah göstermesin.

mâ-dâme'l-hayât: $A r$. Hayat boyunca, hayat devam ettikçe.

mâder-zâd: Far. Anadan doğma, doğuştan, yaratıliştan.

mâhir: Ar. Usta, becerikli.

mahrûm: $A r$. Yoksun.

mahsûl-i hayât: Evlat.

mahzâ: Ar. Ancak, sadece.

mak'ad: Ar. Makat, anus.

maksad-ı aslî: Asıl amaç. 
mâkûs: $A r$. Kötü, zit, ters.

ma'lûl: Ar. Hasta, illetli.

mâlûm-ı enâm: Herkesin malumu.

mâlûm-ı hakâyık-ı bârize: Herkes tarafindan bilinen gerçekler.

maraz-ı mevrûs: (Huy, hastalık vb. için) Anadan babadan geçmiş hastalık.

maraz-ı mühlik: Öldürücü hastalık.

maraz-ı müzmin ve mühlike: Öldürücü ve kronik hastalik.

maraz-ı vahîm: Tehlikeli hastalık.

mârûz kalmak: İstemediği, hoşlanmadığı bir şeyle karşı karşıya kalmak.

masûn: Ar. Korunmuş, muhafaza edilmiş.

ma'tûf: $A r$. Atfedilmiş, yöneltilen, yüklenen.

mâyi': Ar. Sivı.

me'hûzât: $A r$. Gelirler.

mebde': Ar. Başlangıç.

mebzûl: $A r$. Bol, çok.

mebzûlen: $A r$. Bol bol.

mecmûa: Ar. Birikim.

medhaldâr: Ar. + Far. Bir işe tesir eden, bir işte parmağı olan.

mehcûr: Ar. Terk edilmiş, yalnız bırakılmış.

memlû: Ar. Dolmuş, dolu.

memnû́': Ar. Yasaklanmış, yasak.

memnûiyyet: $A r$. Yasaklanma, yasak.

men': Ar. Yasaklama, engelleme.

menba': Ar. Kaynak.

menba'-i kuvvet ve ciyâdet: Temizlik ve güç kaynağı.

merzâ: Ar. Hastalar.

mesâî-i vafîre: Çok ve bol işler. mesâmât: $A r$. Vücûdun teneffüs etmesine ve ter çıkarmasına yarayan cilt üzerindeki küçük delikler, gözenekler, mesam, mesâmeler.

meşâhîr-i etibbâ: Tanınmış, meşhur doktorlar.

meşîme-i mâder: Kadının döl yatağı.

meşrûbât-ı küûliyye: Alkollü içkiler.

mevâdd: $A r$. Maddeler.

mevâdd-ı azotiyye: Azotlu maddeler.

mevâdd-ı ecnebiyye ve muzırra: Zararlı ve yabanc1 maddeler.

mevâdd-ı mesmûme: Zehirli maddeler.

mevâdd-ı muzırra: Zararlı maddeler.

mevâdd-ı semmiyye: Zehirli maddeler.

mevâdd-ı uzviyye: Organik maddeler.

mevcûdât-ı arz: Dünyadaki bütün varlıklar.

mev'id-i telâkî: Bir araya gelinen yer, buluşma noktası.

meyl: Ar. Eğim, eğiklik.

mezâr-ı adem: Yokluk mezarı, ölüm.

mıntıka: $A r$. Vücutta belli kısımlardan her biri, nâhiye.

mıntıka-i mahdûde: Vücutta sınırları belli kısımlardan her biri, nâhiye.

mikyâs: Ar. Ölçü, derece.

mîyâr: Ar. Ölçü, ayar ölçüsü.

muâlece-i husûsiyye: Özel tedavi.

muallak: Ar. As1li.

muammer: $A r$. Uzun ömürlü, uzun bir ömür süren.

muâyene-i tıbbiyye: Tibbi muayene.

muayyen: Ar. Belirli.

mûcib: Ar. Sebep olan, gerektiren.

mûcib-i saâdet: Mutluluk vesilesi, mutluluk sebebi.

mugaddî: $A r$. Besleyici. 
muhâcim: Ar. Hücum eden, saldıran.

muhâceme: Ar. Hücum etme, saldırma.

muharrer: $A r$. Yazılmış.

muhât: $A r$. Etrafi sarılmış, kuşatılmış.

muhâtaralı: $A r .+T$. Tehlikeli, korku ve endişe verici.

muhtasaran: $A r$. Kisaca.

muhtel: Ar. Karışmış, karışık.

mukaddem: Ar. Önce, evvel.

mukaddemâ: $A r$. Bundan önce, eskiden.

mukârebet: $A r$. Yakınlık, akrabalık.

mukâvemet: $A r$. Dayanma, direnme.

mukâvemetsiz: $A r .+T$. Dayanıksız, dirençsiz.

mukâvim: Ar. Dayanıklı, güçlü.

muktezî: Ar. Gerekli olan.

muntazam: $A r$. Düzgün; düzenli.

muntazaman: Ar. Düzenli olarak.

musâb: Ar. Bir hastalığa yakalanmış.

musâdif: $A r$. Rastlayan, tesadüf eden.

musîb: $A r$. Doğru, isabetli.

muvaffakiyyet: $A r$. Başarı.

muvaffakiyyet-i şâfiyye: Şifayla ilgili başarı.

muzirr: Ar. Zarar veren, zararlı.

mübâreze: $A r$. Mücadele.

mübâreze-i tıbbiyye: Tıbbi mücadele.

mübâyaa: $A r$. Satın alma.

mübrem: Ar. Kaçınılmaz, vazgeçilmez.

mübtelâ: Ar. Bir hastalığa tutulmuş.

mücerred: $A r$. Soyut, tecrit yoluyla elde edilen.

müctenib: Ar. Sakınan, uzak duran.

müdâfaât: $A r$. Savunmalar, müdâfaalar.

müdâfi': $A r$. Savunan. müesses: $A r$. Kurulmuş.

müessir: Ar. Etkili.

müfîd: Ar. Faydalı.

müftekir: Ar. Muhtaç.

müheyyâ: Ar. Hazır, âmâde.

müheyyâ-yı hücûm: Hücuma hazır.

mümârese: $A r$. Alıştırma, egzersiz.

mümârese-i bedeniyye: Bedensel alıştırma, egzersiz.

mümârese-i teneffüsiyye: Nefes alma egzersizi.

münbais: $A r$. Bir şeyden dolayı olan, -den ileri gelen.

mündefi‘: Ar. (Hastalık, sıkıntı vb. için) Savulmuş, savuşturulmuş, atlatılmış.

münhasır: $A r$. Sinırl1.

münkalib: $A r$. Başka bir duruma veya şekle dönüşmüş, değişmiş.

münkasım: $A r$. Kısımlara ayrılmış, bölünmüş.

müreccah: $A r$. Tercih edilen.

mürekkeb: Ar. Birleşik.

mürekkebât: $A r$. Mürekkep maddeler, birleşikler.

müsâmaha $A r$. Gerekli dikkat ve ciddiyeti göstermeme, gevşeklik, ihmal.

müsâvâten: $A r$. Eşit olarak.

müsellem: $A r$. Doğruluğu, gerçekliği ispatlanmış.

müsellesü'l şekl: Üçgen şeklinde olan.

müsemmâ: $A r$. İsimlendirilmiş.

müskirât: $A r$. Alkollü içkiler.

müstaid: $A r$. Meyyâl, istîdatl1.

müstâmel: Ar. Kullanılmış, kullanılan.

müsterîh: $A r$. Rahat, huzurlu.

müşâhede: $A r$. Gözlem. 
müşârün-ileyh: Sözü edilen.

mütâlaa: Ar. Etraflıca düşünme, inceleme, tetkik.

müteâkib: Ar. Birbiri ardınca gelen, birbirini takip eden.

müteassir: Ar. Zor, güç, zahmetli.

mütecâsir: $A r$. Bir davranışı yapmaya kalkışan, yeltenen, cüret eden.

müteessir: $A r$. Etkisi altında kalan, etkilenen.

müteferrik: $A r$. Birbirinden ayrılmış, dağılmış.

mütemâyil: Ar. Meyleden, meyilli.

müterâkim: $A r$. Birikmiş, toplanmış.

müterakkib: Ar. Gözetleyen, bekleyen.

müteselsilen: Ar. Zincirleme olarak, peş peşe.

mütevakkıf: $A r$. Bağlı.

müteveccih: $A r$. Yönelmiş, yönelen.

mütevellid: $A r$. -den doğmuş, ileri gelmiş.

müteverrim: $A r$. Verem hastalı̆̆ına yakalanmış (erkek).

müteverrime: $A r$. Verem hastalığına yakalanmış (kadın).

müteyakkız: $A r$. Dikkatli, uyanık, tetikte.

müvellidü’l-humûza: Oksijen.

müvellidü'l-mâ': Hidrojen.

müzmin: $A r$. Kronik.

$\mathbf{N}$

nâfi': Ar. Faydalı.

nâfiz: $A r$. İçe işleyen, çok tesir eden, etkili.

nahîf: $A r$. Zayıf, çelimsiz.

nâ-kâbil-i redd: Reddedilmesi imkansız.

nâmzed: Far. Aday.

nâsûr: $A r$. Fistül.

nâ-tüvânî: Far. Güçsüzlük.

nef': Ar. Fayda. neşv ü nemâ: Gelişme, büyüme.

nevzâd: Far. Yeni doğmuş.

nezâret: Ar. Gözetim, kontrol.

nezâret-i mütemâdiyye: Devamlı gözetim, kontrol.

nezle-i müstevliye: Grip, salgin nezle, influenza.

nigeh-bân-ı sıhhî: Sağlık bekçisi.

nisbet-i sâbite: Sabit oran.

nişân-ı felâket: Felaket alâmeti, işareti.

noksânî: $A r$. Noksanlık, eksiklik.

$\mathbf{P}$

pâyidâr: Far. Kalıc1, devamlı, sâbit.

pott: Spinal tüberküloz.

$\mathbf{R}$

rahm-ı mâder: Anne rahmi, döl yatağı.

rakîk: $A r$. İnce.

re'y: Ar. Görüş, düşünce.

refîk: $A r$. Koca, zevç.

refîka: $A r$. Karı, zevce.

riâyet: $A r$. Uyma, itaat etme.

rüchân: $A r$. Üstünlük.

S

sadâ: $A r$. Ses.

sâfiyyet: $A r$. Saflık.

sâfiyyet-i hevâiyye: Havanın temizliği.

sâhib-i vukûf: Anlayıs ve bilgi sahibi.

sâkinâne: $A r .+F a r$. Sâkince.

sanatoryum: $F r$.<Lat. Özellikle verem hastalarının tedâvi ve bakımının yapıldığı sağl1k kurumu.

sarf-ı nazar: Vazgeçme, hesaba katmama.

sarfiyyât: $A r$. Sarfedilen, harcanan şeyler.

sârî: Ar. (Hastalık için) Bulaşıcı.

sath: Ar. Bir şeyin dış tarafı, yüzü. 
sebk: $A r$. İleri geçme, üstünlük sağlama.

sefâlet-i bedeniyye: Bedensel perişanlık, sefillik.

sehîl: $A r$. Kolay.

sehlü'l-hazm: Sindirimi kolay.

sekte-dâr: $A r .+F a r$. Sekteye uğramış, düzeni bozulmuş.

sem-âlûde: Ar.+Far. Zehire bulaşmış, zehirli. sem-dâr: Ar.+Far. Zehiri olan, zehirli.

semere: $A r$. Beklenen sonuç, netice.

semm: Ar. Zehir, ağu.

seretân: $A r$. Yenirce denen hastalık, kanser.

seyelân-ı ebyaz: Beyaz akıntı.

sezâ: Far. Uygun.

sıklet: $A r$. Ağırlık.

sıklet-i bedeniyye: Bedensel ağırlık.

sıraca: Daha ziyâde çocuklarda ve gençlerde görülen, boyun ve koltuk altlarındaki lenf bezlerinde iltihaplanmalara ve akintılı yaralara yol açan bir çeşit verem.

si'a-i teneffüsiyye: Solunumla ilgili güç, tâkat.

si'a-i sadriyye: Göğüsle ilgili güç, tâkat.

sillü'r ri'e: $A r$. Akciğer veremi.

sinn-i bülûğg: Ergenlik çağ1.

sirâyet: Ar. (Hastalık için) Geçme, bulaşma.

sû'-i igtidâ: Kötü beslenme.

sû'-i istîmâl: Kötüye kullanma.

sû'-i te'sîr: Kötü, olumsuz etki.

su'âl: $A r$. Öksürük.

sukût: $A r$. (Çocuk için) Zamanından önce doğma, düşük.

sûret ve sür'at-i tedâvî: Tedavi hızı ve şekli.

sûret-i dâime: Daima, her zaman.

sûret-i kat'iyye: Kesinlikle. sûret-i matlûbe: İstenildiği, talep edildiği şekil.

sûret-i tagaddî: Beslenme şekli.

sûret-i tedâvî: Tedavi şekli.

suûbet: $A r$. Zorluk, güçlük, zahmet.

sübût-ı intikâl: Sirâyet etme, bulaşma gerçekliği.

sühûlet: Ar. Kolaylık.

sühûlet-i duhûl ve nüfûz: İçe girme ve işleme kolaylığı.

sühûlet-i hazm: Sindirim kolaylığı.

sühûlet-i teneffüs: Solunum kolaylığı.

sükûnet-engîz: Ar.+Far. Sessizlik veren.

sümûm: $A r$. Zehirler.

Ş

şâbâş-ı şu'â'ât: Güneş 1şınlarının takdiri.

şâbâş-ı ziyâiyye: Işıklı takdir, parıltılı beğeni. şâfî: $A r$. Şifa veren, iyileştirici.

şahm: $A r$. İç yağı.

şark: Ar. Doğu.

şâyân-ı dikkat: Dikkate değer.

şâyân-ı kayd: Kayda değer.

şâyân-ı rüchân: Üstün olmaya değer, üstünlüğe lâyık.

şâyân-ı tavsiye: Tavsiye etmeye değer.

şedîd: $A r$. Şiddetli, sert.

şiddet-i tenebbüt ve semmiyyet: Zehirleme ve büyüme derecesi.

şifâ-pezîr: Ar.+Far. Tedavi edilebilir, iyileşebilir.

şifâ-yâb: $A r .+F a r$. Şifa bulan, iyileşen.

şimâl-i şarkî: Kuzeydoğu.

şitâbân: Far. Acele ile giden, koşan.

T

taab: Ar. Yorgunluk. 
taâm: $A r$. Yemek, aş.

taammüm: Ar. Yayılma, genelleşme.

ta'azzuv: Ar. Gelişme.

tabâbet-i hâżra-i Osmâniyye: Bugünkü Osmanlı tip ilmi.

tabh: Ar. Pişirme, pişirilme.

tafsîlât-ı ma'rûza: Arz edilmiş, sunulmuş olan açıklamalar.

tafsîlât-ı tedâvîkârâne: Tedavi edici açıklamalar.

tagaddî: $A r$. Beslenme.

tagayyürât: $A r$. Değişmeler; bozulmalar.

tahaffuz: $A r$. Sakınma, korunma.

taharrî: Ar. Arama, bir şeyi bulmaya çalışma.

tahavvül: $A r$. Değişme, bir halden başka bir hâle geçme.

tahavvülât: $A r$. Değişiklikler.

tahavvülât-ı hevâiyye: Hava değişimleri.

tahdîd: Ar. Sinırlama.

tahdîden: $A r$. Sınırlama olarak.

tahdîd-i tahrîbât: Tahripleri, zararı sinırlandırma.

tahfif: $A r$. Hafifletme.

tahkîkât: Araştırma, soruşturma.

tahlîs-i girîbân eylemek: Yakasını kurtarmak, yakayı sıyırmak.

tahrîb: $A r$. Harap etme.

tahrîbât: $A r$. Tahripler; zarar.

tahrîk: Ar. Harekete geçirme.

tahte'l-cild: Deri altı.

takallüs: Ar. Asabî ve rûhî bir gerginlikten veya başka sebeplerden ileri gelen kas çekilmesi, kasılma, büzüşme.

takarrür: Ar. Yerleşme.

takayyüdât-ı tıbbiyye: Tibbi çalışmalar, gayretler. ta'kîm: Ar. 1. Akâmete uğratma, sonuçsuz bırakma; 2. Sterilizasyon, mikropsuzlaştırma.

taksîm: $A r$. Bölme.

ta'lîk: Ar. Asma, asılma.

tâmmü'l 'âfiyye: S1hhatli, sağlığı yerinde.

tarafeyn: $A r$. Her iki taraf.

târî olmak: Ortaya çıkmak, belirmek.

ta'rîk: $A r$. Terletme.

tasfiye: $A r$. Pâk ve temiz duruma getirilme, saflaştırılma, arıtılma.

tas'î́b: $A r$. Güçleştirme, zor duruma sokma.

te'hîr: Ar. Geciktirme.

te'mîn: Ar. Hazırlama, sağlama.

tebâ'id: Ar. Uzaklaşma.

tebeddül: $A r$. Değişme.

tecârib: $A r$. Tecrübeler.

tecemmu': Ar. Toplanma, yığılma.

tecezzî: $A r$. Bölünme, küçük parçalara ayrilma.

tedâbîr-i ihtiyâtiyye: İhtiyâtî tedbirler.

tedâbîr-i sıhhiyye: Sağlıkla ilgili tedbirler.

tedâvî-i hevâiyye: Hava tedavisi.

tedâvî-i şâfî: İyileştirici tedavi.

tedkîk: $A r$. İnceleme.

tedkîkât: $A r$. İncelemeler.

tedkîkât-ı amîka: Derin incelemeler.

tedrîcen: Ar. Yavaş yavaş.

tefrîk: Ar. Ayırma.

tehâcüm: $A r$. Bir yere hücum etme, toplanma.

tehyîc: $A r$. Heyecanlandırma, coşturma.

tekessür: Ar. Çoğalma.

teksîr: $A r$. Çoğaltma.

telâfî: $A r$. (Bir ziyânı, bir eksiği) Karşılama, yerini doldurma. 
telâfi-i mâfât: Elden çıkan bir şeyin karşılığında bir başka şey elde etme, kaybedilen şeyi başka bir şeyle karşılama.

telakkî: Ar. Kabul etme; görüş, anlayış.

telef olmak: Ölmek.

temâruz: $A r$. Kendini hasta gibi gösterme.

temekkün: $A r$. Yerleşme.

tenâkus: Ar. Azalma, eksilme.

tenbîh: Ar. Uyarma, uyarı, stimulation.

tenebbüt: Ar. Büyüme, gelişme.

teneffüs: $A r$. Nefes alıp verme, soluma, solunum.

tenkîs: Ar. Azaltma.

tensîb: Ar. Uygun bulma.

terâküm: Ar. Yığılma, toplanma, birikme.

tereffu': $A r$. Yükselme.

terk-i enfâs etmek: Ölmek.

tertîbât: $A r$. Ön hazırlıklar, önlemler.

tesemmüm: Ar. Zehirlenme.

teshîl: $A r$. Kolaylaştırma.

te'sîrât: $A r$. Tesirler, etkiler.

te'sîrât-ı hasene: İyi etkiler.

te'sîr-i sem-dâr: Zehirleyici etki.

te'sîr-yâb: Ar.+Far. Tesir bulan, etkili.

teskîn: Ar. Yatıştırma, sükûnete erdirme.

teslîm-i hayât etmek: Ölmek.

tesmîm: $A r$. Zehirleme.

tesmîmât: $A r$. Zehirlemeler.

tesrî́: Ar. Hızlandırma, çabuklaştırma.

teşdîd: $A r$. Şiddetini arttırma.

teşhîs: $A r$. Araştırarak bir hastalığın ne olduğunu belirleme, adını koyma, tanı.

teşmîl: $A r$. Bir şeyi kapsamı içine alma. teşrîh Ar. Açılama. tevakkî: $A r$. Sakınma, ihtirâz.

tevellüd: $A r$. Dünyaya gelme, doğma.

teverrüm: $A r$. Verem olma, vereme yakalanma.

tevessü': $A r$. Genişleme.

tevlîd: Ar. Sebep olma, yol açma, doğurma.

tevlîd-i emrâz: Hastalıklara sebep olma.

tevsî‘: Ar. Genişletme.

tevzî́: $A r$. Dağıtma.

tezâuf: $A r$. İki misli olma.

tezâyüd: $A r$. Çoğalma, artma.

tezkâr: Ar. Hatırlama, hatıra getirme.

tufeylât-ı sagîre: Küçük parazitler.

tüberkül: Verem habbeciği $b k$. hubeyb-i derenî

tükürük hokkası: Tükürük kab1, tükürügün konulduğu küçük kap.

$\mathbf{U}$

ukde-i lenfâviyye: Lenf bezleri.

usret: Ar. Zorluk.

usret-i teneffüs: Nefes darlığ1.

uzv: Ar. Organ.

uzvî: Ar. Organik.

V

vâkî: $A r$. Hastalı̆̆ı önleyen (tedbir).

vâridât: $A r$. Gelirler.

vâsıta-i intikâl: Geçme, sirâyet aracı.

vâsıta-i sirâyet: Bulaşma aracı.

vâsi': Ar. Geniş.

vazife-i ifrâg: Boşaltım görevi.

vehâmet: $A r$. Tehlike.

verâset: $A r$. Soyaçekim, kalıtım.

vird-i zebân eylemek: Dilinden düşürmemek, hep tekrarlamak. 
verem: $A r$. Vücutta herhangi bir organa, özellikle de akciğgerlere yerleșen Koch basilinin yol açtığı bulaşıcı, ateşli hastalık, tüberküloz.

vesâit-i tıbbiyye: T1bbi araçlar.

vesâyâ: $A r$. Öğ̈̈tler, nasihatler.

vesâyâ-yı ma'rûza: Arz edilmiş olan öğütler, nasihatler.

vesâyâ-yı sıhhiyye: Sağlıkla ilgili öğütler, nasihatler.

vezâif: $A r$. Görevler.

vezâif-i hayâtiyye: Önemli görevler.

vücûd-ı beşer $b k$. vücûd-ı insânî

vücûd-ı insânî: İnsan vücudu.

Y

yed-i iktidâr ve ihtimâm: İtina ve kudretin elde tutulmasi.

yegân yegân: Far. Birer birer.

yekdiğeri: $\quad F a r .+T$. (İyelik ekinin kalıplaşmasıyla) Birbiri.

yekûn: Ar. Toplam.

$\mathbf{Z}$

za'fiyyet: $A r$. Zâfiyet, zayıflık; güçsüzlük, halsizlik. zâhir: Ar. Görünen, açık, belli.

zahr: Ar. Arka, arka taraf.

za'îf: $A r$. Zayıf.

zamân-ı tufûliyyet: Çocukluk dönemi.

zarar-ı mahz: Tam zarar.

zâtü'l-cenb: Ar. Akciğer veya göğüs zarı iltihâb1, satlıcan.

zebân-zed: Far. Kullanılması yaygınlaşmış olan söz.

zebûn: Far. Güçsüz, zayıf.

zehr-nâk: Far. Zehirli.

zevâl: $A r$. Yok olma, ortadan kalkma.

zevc: $A r$. Koca, eş.

zevce: $A r$. Bir erkeğin nikahlı eşi, karısı.

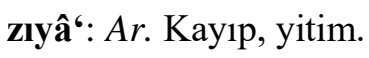

zıyâ'-1 harâret-i bedeniyye: Vücuttaki 1S1 kayb1.

zıyâ'-1 kuvvet: Güç kaybı.

ziyâsızlık: $A r .+T$. Işıksızlık.

ziyâ-yı şems: Güneş 1şınları.

zuhûr eylemek: Meydana çıkmak, görünmek.

zülâliyyât: Ar. Albüminli (maddeler).

\section{Sonuç}

Salgınlar yüzyıllar boyu toplumları etkisi altına almış ve pek çok can kayıplarına sebep olmuştur. Özellikle de günümüzde iletişim ve ulaşım olanaklarının artması beraberinde "salgın" başlı̆̆ı altında inceleyebileceğimiz enfeksiyon hastalıklarının yayılımını da daha kolay hâle getirmiştir. Bu tür hastalıkların yayılımı ise iki başlık altında toplanır: Epidemi ve pandemi. Tıp alanında epidemi ve pandemi konusunda pek çok çalışma yapılmakla birlikte bu iki kavram ayrıca tıp tarihi, tarih, sosyoloji, psikoloji, ekonomi, uluslararası ilişkiler, edebiyat gibi disiplinlerin de araştırma alanlarından olmuştur.

Tarihte "müzmin" ve "mühlik" olarak kabul edilen salgın hastalıklardan bir tanesi de veremdir. Hüseyin Kâmî, Emrâz-ı Müzmine ve Sâriyeden Verem: İbtidâsı, Edvârı, Sûret-i Tevakkî ve Tedâvîsi başlıklı eserinde toplumsal konulara olan ilgisini bir edebiyatçı duyarlılığı içinde ortaya koyar ve halkı verem hastalığı ile ilgili uyarmayı bir vazife addeder. "Birkaç Söz" bahsinde “...bu marazın pençe-i 'akûrunda her gün bir çok gençlerimiz zâr u zebûn inlemektedir.”, “...maraz bütün şiddetiyle, 'akûr dişleriyle zavallı beşeriyyete saldırmaktan yine hâlî kalmıyor" diyerek verem salgınından binlerce kişinin ölümüne duyduğu üzüntüyü dile getirir. Bu hastalığı diğer vahim 
hastalıklarla da mukayese ederek sözlerine şöyle devam eder: Veba, kolera gibi "emrâz-1 müstevliye" (salgın hastalıklar)'ye gösterilen hassasiyetin aynı şekilde vereme de gösterilmesi gerekir. Verem denilen "âfet-i maraziyye" (hastalık belâsı)'yi veba ve koleradan ayıran bir diğer husus da irsî olmasıdır. Müteverrim bir babanın ve müteverrime bir annenin çocuklarının da bu hastalı̆̆ın pençesine düşme ihtimali yüksektir. Yazar, beynelmilel bir hastalık şeklini alan bu hastalıktan korunma tedbirlerini ve hastalığın iyileştirilmesi hususunu çok açık bir dille ailelere anlatma gereği duyduğunu ve bu sebeple Fransızcadan yaptığı tercümeleri bir araya getirip okuyucuların dikkatine sunduğunu ifade ederek eseri yazma amacını da beyan eder. Bu çalışmasıyla aynı zamanda salgınlarda hep birlikte mücadelenin önemini zikreder.

Eser, veremi bütün yönleri ile ele alan derli toplu bir çalışma olması bakımından ayrı bir önem taşımaktadır. Söz varlığı açısından bakıldığında ise; Türkçe, Arapça, Farsça ve Batı dillerinden alınmış pek çok kelimenin yanı sıra bu dillerden terimler de ihtiva etmektedir. Türkçe terimler böbrek, girtlak, kasık, göz bebeği, bel ăgrlsı, çıban, ses kısıklı̆̆ı, boğuklaşma gibi organ ve hastalık adlarında; çĭ̆ yumurta, et, yoğurt, süt, buğday, ekmek gibi gıda maddelerinde görülmektedir. Batı kökenli terimler daha çok kimya ve bazı tıp terimlerinde karşımıza çıkmaktadır: Sodyum, azot, manganez, kalsiyum, potasyum, flor, klor, fosfor, pott, koch basili, sanatoryum, lenfa. Arapça ve Farsça kelimeler ile Arapça Farsça tamlama yapısındaki terimler ise hastalık adları, organ adları, vücut sağlığını ifade eden terimlerde daha yaygın kullanılmıştır: Küreyvât-ı beyzâ, meşîme-i mâder, cihâz-ı hazmiyye, sillü'r ri'e, fakrü'd-dem, seyelân-ı ebyaz, nâsûr, seretân, em 'â, gışâa. Eserde az da olsa Arapça ve Farsça kimya terimleri bulunmaktadır: hadîd, müvellidü'l-mâ', müvellidü'l-humûza, fahm, kükürt. Dolayısıyla, tarafimızdan hazırlanmış olan terim ağırlıklı metin sözlügü ile bundan sonra hazırlanacak olan terim sözlüklerine katkı sağlaması amaçlanmıştır.

\section{Kaynakça}

Barış, Y.İ. (2010). “Dünyada Tüberkülozun Tarihi.” Konuralp Tıp Dergisi. 3 (2): 1-4.

Dilçin, C. (1983). Yeni Tarama Sözlüğ̈̈. Türk Dil Kurumu.

Kâşif Dehrî. (1331/ Milâdî 1915). Emrâz-ı Müzmine ve Sâriyeden Verem: İbtidâsl, Edvârl, Sûret-i Tevakkî ve Tedâvîsi. Sancakciyan Matbaasi.

Kayaokay, İ. (2019). “Türk Masal Araştırmacılığında Yüz Yıllık Bir Muamma: Bir ‘Hanım’ Olduğu Sanılan 'K.D.' Müstear Adı Kime Aittir?” Hikmet-Akademik Edebiyat Dergisi [Journal of Academic Literature]. 5: 304-317.

Koç, A. (2010). “Hastalık İsimlerinde Örtmece.” Türk Dünyası Araştırmaları Dergisi. 188: 77-95.

Sarıca, A. (2012). Hüseyin Kâmi’nin Hayatı ve Eserleri [Yayımlanmamış yüksek lisans tezi]. Uşak Üniversitesi Sosyal Bilimler Enstitüsü.

Tekin, A. (2007). Sağglı-Hastalık Olgusu ve Toplumsal Kökenleri (Burdur örneği). [Yayımlanmamış yüksek lisans tezi]. Süleyman Demirel Üniversitesi Sosyal Bilimler Enstitüsü.

Türk Dil Kurumu (2011). Türkçe Sözlük. Türk Dil Kurumu.

Unat, E.K. \& İhsanoğlu, E. \& Vural, S. (2004). Osmanlıca Tıp Terimleri Sözlüğü. Türk Tarih Kurumu.

Yalçın, Ö. (1981). “Şarkışla Folklorunda Verem.” Türk Folkloru Aylık Folklor Dergisi. 26: 23-25. 